\title{
SOME REFLECTIONS ON THE RELATIONSHIP BETWEEN THE PRINCIPLE OF EQUITABLE UTILIZATION OF INTERNATIONAL WATERCOURSES AND THE OBLIGATION NOT TO CAUSE TRANSFRONTIER POLLUTION HARM*
}

\author{
Shigeta Yasuhiro**
}

\section{INTRODUCTION}

Under customary international law, States have the obligation to prevent, with due diligence, the occurrence of a serious level harm by pollution [hereinafter, pollution harm] in other States caused by activities within its own territory. By violating this obligation they bear responsibility for an international wrongful act. ${ }^{1}$

This obligation of prevention seems to be equally applicable ${ }^{2}$ in the case

\footnotetext{
* In its original version this paper appeared in Japanese in Hogaku Ronso [Kyoto Law Review] Vol.135 No.6 (September 1994), pp. 19-43, and Vol.137 No.3 (June 1995), pp. 42-62. The present, revised, version has taken account of the 1997 Watercourses Convention and the 1997 decision of the ICJ in the Gabcíkovo-Nagymaros Project case.

** Osaka Gakuin University, Osaka.

1 See the Trail Smelter case (Final Decision), The United States/Canada, (Arbitration, 11 March 1941), 3 RIAA 1907 at 1965; Ian Brownlie, System of the law of nations: state responsibility, part I (Oxford: Clarendon Pr., 1983) 182. For this matter, see this author, "Territorial sovereignty and transfrontier pollution by a nuclear accident: a legal analysis of the Chernobyl accident" (in two2 parts, in Japanese), 131 Hogaku Ronso [Kyoto Law Review] no. 2 (1992) 97, 133 Hogaku Ronso no. 2 (1993) 63.

2 See Nisuke Ando, "The law of pollution prevention in international rivers and lakes", in Ralph Zacklin \& Lucius Caflisch (eds.), The legal regime of international rivers and lakes (The Hague: Nijhoff, 1981) 331 at 333-337; Lucius Caflisch, "Régles générales du droit des cours d'eau internationaux", in 219 RdC (1989) 9 at 167; Johan G. Lammers, Pollution of international watercourses (Boston: Nijhoff, 1984), at 583; Stephan C. McCaffrey, Fourth report on the law of the non-navigational uses of international watercourses [hereinafter, Fourth Report], YILC, 1988, Vol. II, Part One, 205, at 217-245; Jörg G. Polakiewicz, "La responsabilité de l'État en matiére de pollution des eaux fluviales ou souterraines internationales", 118 Journal de Droit International (1991) 283 at 300-301; Kurao Tsukikawa, "The prevention of pollution in international drainage basins" (in Japanese), 77 Kokusaiho Gaiko Zassi [The Journal of International Law and Diplomacy] (1979) 594 at 626.
}

Asian Yearbook of International Law, Volume 9 (B.S. Chimni et al., eds.)

(C) 2004 Koninklijke Brill NV. Printed in The Netherlands, pp. 147-189. 
of pollution of international watercourses. ${ }^{3}$ For example, the Lake Lanoux arbitral award $^{4}$ of 1957 affirmed the possibility of the occurrence of injury, by pollution, to rights of Spain, a downstream State of an international watercourse. ${ }^{5}$ In addition, the Strasbourg Administrative Tribunal in France and the District Court of Rotterdam in the Netherlands held in 1983 in the Mines de Potasse d'Alsace case ${ }^{6}$ as follows:

[L]'administration doit veiller a ne pas permettre des activites pouvant avoir hors du territoire national des consequences nuisibles, graves et anormales. ... il resulte ... de facon generale des principes consacres par le droit international ... que, lorsqu'elle envisage d'autoriser des rejets susceptibles d'alterer de facon notable la qualite des eaux hors des limites du territoire national, l'administration doit ... rechercher de facon precise les effets a l'etranger des deversements en cause.... ${ }^{7}$

Another principle of international law provides that no State has the right to cause serious injury to the territory of another State or to its inhabitants.

\footnotetext{
3 Article 2 of the Convention on the Law of the Non-navigational Uses of International Watercourses (adopted by the United Nations General Assembly in 1997, hereinafter "1997 Watercourses Convention"), defines "international watercourse" as follows: “(a) 'Watercourse' means a system of surface waters and groundwaters constituting by virtue of their physical relationship a unitary whole and normally flowing into a common terminus; (b) 'International watercourse' means a watercourse, parts of which are situated in different States. 36 ILM (1997) 704. Therefore, waters of international watercourses include surface waters and groundwaters of rivers, lakes, aquifers, glaciers, reservoirs and canals. See Report of the International Law Commission on the work of its forty-sixth session (2 May - 22 July 1994) [hereinafter, 1994 ILC Report], UN Doc., GAOR, Forty-Ninth Session, Supp. No. 10 (A/49/10), at 200.

4 The Lac Lanoux case, Spain / France (Arbitration, 16 November 1957), 12 RIAA 281.

5 Id., at 303. Although the Additional Act to the Treaty of Bayonne contains no special provision for pollution, Article 12 of that Act prescribes the prohibition of a change in the natural condition of the waters. See id., at 289. Therefore, the Court apparently held that a violation of the provision in question would take place if pollution occurs. Gunther Handl, "Balancing of interests and international liability for the pollution of international watercourses: customary principles of law revisited", 13 Canadian Yearbook of International Law [hereinafter, CYIL] (1975) 156 at 169-170.

${ }^{6}$ In this case, gardeners in the Netherlands were injured by salt dumping into the Rhine river carried out by the mine in question located in France. See Lammers, op. cit. n. 2, at 196-206; Polakiewicz, op. cit. n. 2, at 321-325.

${ }^{7}$ La Province de la Hollande septentrionale et autres c. Etat-Ministre de l'Environnement [Commissaire de la Republique du Haut-Rhin] (Le Tribunal Administratif de Strasboug, 27 July 1983), 44 ZaoRV (1984) 342 at 344. While in this suit it was disputed whether the order issued by a prefectural governor of France authorizing the salt dumping by the said mine was null and void, in this judgment it was so declared. See id., at 345. The Conseil d'Etat, to which this case was appealed, supported the previous decision of the lower court because of the violation of domestic procedures without calling into question the violation of international law. Conseil d'Etat, Recueil des Decisions $d u$ Conseil d'Etat, 3 Mars - 30 Avril 1986 (18 avril 1986) at 116-118.
} 


\section{... This principle ... is applicable ... similarly to the pollution of international rivers. $^{8}$}

However, if the pollutants in question come from developing countries which have only recently begun with activities causing pollution, and are introduced into components of the ecosystem that are already more or less affected by pollutants from developed countries, the strict application of the obligation not to cause transfrontier pollution harm [hereinafter, the no pollution harm principle $]^{9}$ would generate inequitable results. The developing countries would necessarily be deemed to have caused pollution harm and would bear responsibility for it. Therefore, some scholars ${ }^{10}$ who support the doctrine of equitable utilization of "shared natural resources"

\footnotetext{
${ }^{8}$ Handelskwekerij G.J. v. Mines de Potasse d'Alsace S.A., (District Court of Rotterdam, 16 December 1983), 15 Netherlands Yearbook of International Law [hereinafter, NYIL] (1984) 471 at 480. Although in this decision the existence of a delict under Dutch municipal law was found out because of the absence of due diligence of the said mine, it was stated that application of the unwritten rules of international law did not lead to a conclusion different from the aforementioned. See id., at 479, 481. Later, decisions concerning this case were held by the Court of Appeal of The Hague in 1986 and the Supreme Court of the Netherlands in 1988, both of which recognized the liability of the said mine, without calling into question the violation of international law. Court of Appeal of The Hague, 10 September 1986, 19 NYIL (1988) at 496-503; Supreme Court, 23 September 1988, 21 NYIL (1990) at 434-440.

9 When we use the term "the obligation not to cause transfrontier (pollution) harm" ("the no (pollution) harm principle") in this paper, we do not intend to give any connotation to this term in respect of whether this obligation includes the concept of due diligence, nor how much is the level of harm to be prevented.

${ }^{10}$ See Article 3 of ILA Montreal Rules of International Law Applicable to Transfrontier Pollution (1982), cited in Experts Group on Environmental Law of the World Commission on Environment and Development, Environmental protection and sustainable development (London: Graham \& Trotman, 1987), at 187; Article 9 of Legal Principles for Environmental Protection and Sustainable Development (1986), id., at 72-75. See also Handl, "Principle of 'equitable use' as applied to internationally shared natural resources: its role in resolving potential international disputes over transfrontier pollution”, 14 Revue Belge de Droit International (1978-1979) 40 at 45-46; Atsuko Kanehara, "The significance of the 'pledge and review' procedure in growing international environmental law " (in Japanese), 38 Rikkyo Hogaku [St. Paul's Review of Law and Politics] (1994) 46 at $48-55$.

${ }^{11}$ In the view of Schwebel, the Special Rapporteur of the ILC on Watercourses, the concept of "shared natural resources" had, despite the absence of the definition thereof, been widely accepted and the water of an international watercourse was its archetype. Stephen M. Schwebel, Second Report, YILC, 1980, Vol. II, Part One, at 180, paras. 140-141, at 187, para. 174. However, there was also much objection to that concept, mainly because of its uncertainty and possible injury to the permanent sovereignty over natural resources. Consequently, that term has been unused since Evensen's second report. See 1983 ILC Report, YILC, 1983, Vol. II, Part Two, at 70-71, paras. 236-241; 1984 ILC Report, YILC, 1984, Vol. II, Part Two, at 93, para. 315. In this paper, we understand this concept as components of the ecosystem situated between two or more States, especially focusing on the five examples below given by the United Nations Environment Program (UNEP): (a)An international water system, including both surface and ground waters; (b)An air-shed or air mass above the territories of a limited number of States; (c)Enclosed or semi-enclosed seas
} 
that, even if the pollution harm would normally be regarded as unlawful in the light of the no pollution harm principle, a situation could occur where the State of origin would not incur responsibility because the minimum level of harm that has to be prevented is raised by the said doctrine. ${ }^{12}$ However, since the minimum level of harm to be prevented would have to be decided on the basis of the various circumstances of the State of origin, such as the economic needs for the activity in question, the pollution prevention standard would become quite ambiguous. ${ }^{13}$ Therefore, it is considered that the "relaxation" of the no pollution harm principle by the said doctrine constitutes a dangerous proposition. This paper will attempt to prove that the no pollution harm principle is not, in principle, eased by the principle of equitable utilization of international watercourses [hereinafter, the equitable utilization principle]. The conclusion to be drawn from this analysis should be instructive also in considering the relationship between the no pollution harm principle and the doctrine of equitable utilization of "shared natural resources" other than international watercourses.

Let us start by determining our objects of consideration and our premises. The objects of consideration in this paper are limited to the following two items. First, among many kinds of transfrontier harm caused by the use of international watercourses, the focus is on pollution harm. Therefore, this paper does not intend to suggest an extension of its conclusions to other cases, such as those where the harm in another State is caused by the decrease of the amount of water of the international watercourse as a result of the diversion of the water. Secondly, we have limited our object to transfrontier pollution which derives from one State's territory and reaches another State's territory. ${ }^{14}$ Therefore, the following problems are not considered: the pollution of water flowing from a State's territory to areas beyond the limits of national jurisdiction such as the high seas; and the pollution of water flowing from areas beyond the limits of national jurisdiction into a State's territory. Next, this article rests on the following two premises: first, the existence of two levels of harm, that is, a lower level (appreciable=significant)

and adjacent coastal waters; (d)Migratory species which move between the waters or territories of several States; (e)A special ecosystem spanning the frontiers between two or more States, such as a series of mountains, forests or areas of special conservation nature. Co-operation in the field of the environment concerning natural resources shared by two or more states, UNEP/GC/44 (20 February 1975), at 40-41.

12 See Handl, "National uses of transboundary air resources: the international entitlement issue reconsidered", 26 Natural Resources Journal (hereinafter, NRJ) (1986) 405 at 415-416; Magraw et al., Fourth report of the international committee on legal aspects of long-distance air pollution [hereinafter, Fourth Report on LDAP], ILA, Report of the sixty-fifth conference held at Cairo (1992) at 26, para. 91; André Nollkaemper, The legal regime for transboundary water pollution: between discretion and constraint (Dordrecht: Nijhoff, 1993), at 66-69.

${ }^{13}$ Lammers, "Balancing the equities in international environmental law", in René-Jean Dupuy (éd.), L'avenir du droit international de l'environnement (The Hague: Nijhoff, 1985), at 162-163.

14 See Article 2 of ILA Montreal Rules, op. cit. n. 10. 
and a higher level (serious), in accordance with the understanding of the International Law Commission [hereinafter, ILC] ${ }^{15}$; secondly, the understanding that the "relaxation" of the no (pollution) harm principle by the equitable utilization principle means the raising of the level of harm to be prevented.

\section{PRELIMINARY CONSIDERATIONS}

\subsection{The essence of the No Pollution Harm principle and the Equitable Utilization principle}

\subsubsection{The essence of the no pollution harm principle: prevention of factual harm}

To begin with, we should make it clear that the no pollution harm principle is substantively different from the equitable utilization principle. This is necessary because, depending on our understanding of the no pollution harm principle, the two principles may have the same substance. This has already been suggested in McCaffrey's second report on international watercourses to the ILC. ${ }^{16}$

While McCaffrey recognized the obligation not to cause appreciable harm to other watercourse States, he emphasized that the prohibition refers to conduct by which one State deprived another State of its equitable share of the uses and benefits of the watercourse. According to him, the focus was on the duty not to cause "legal injury" (by making a non-equitable use) rather than on the duty not to cause "factual harm". In this way, he tried to evade a conflict between the equitable utilization principle and the sic utere tuo principle by arguing that, within the range of an equitable use, the legal

\footnotetext{
15 According to the commentary to Article 7 of the Provisional Draft, appreciable harm means the harm which, involving a real impairment of use, is capable of being established by objective evidence, and which, though not insignificant or barely detectable, need not rise to the level of being substantial or serious. See 1987 ILC Report, YILC, 1987, Vol. II, Part Two, at 29, para. (16); 1988 ILC Report, YILC, 1988, Vol. II, Part Two, at 36, para. (5). Since Rosenstock's First Report of 1993, the adjective "significant" has been used instead of that of "appreciable" in the ILC on the understanding that both adjectives have the same meaning. See Robert Rosenstock, First Report, UN Doc., A/CN.4/451 (20 April 1993), at 6, para. 12; 1994 ILC Report, op. cit. n. 3, at 211-212, paras. (13)-(15); 36 ILM (1997) 719. We follow in this paper the understanding of the ILC as to the levels of harm as indicated by these adjectives. However, since the adjective "substantial" tends to be differently understood depending on authors, we use this adjective only for direct citations from decisions, treaties, resolutions or writings, etc., and only use the adjective "serious" as indicating "considerable size or amount". When we use the term "serious", we regard the understanding of the Trail Smelter arbitral award as providing prima facie criteria thereof: that is, the harm of such a "size or amount" as causing "economic harm derived from physical harm" amounting to 78,000 dollars in the year of 1938. See this author, op. cit. n. 1, Part 2, at 75-76.

${ }_{16}$ McCaffrey, Second Report, YILC, 1986, Vol. II, Part One, at 133-134, paras. 179-184.
} 
interests of other States are not injured even if an appreciable level of "factual harm" has occurred. As a consequence of distinguishing between "factual harm" and "legal injury", Article 7 and Article 21, paragraph 2, of the Provisional Draft, providing for the no (pollution) harm principle, uses the term "harm", which has only factual connotations, rather than the term "injury", which has legal as well as factual connotations. ${ }^{17}$

Just as seen in the ILC's discussions, the existence of an obligation to prevent "factual harm" rather than "legal injury" is generally accepted in judicial precedents. For example, in the Trail Smelter case, the Arbitral Tribunal decided that the harm which had occurred or was likely to occur in the United States was serious or material and ordered compensation or the adoption of a prevention regime for the harm, not in respect of the harm that exceeded an equitable use by Canada, but in respect of the objective nature of the harm. ${ }^{18}$ Moreover, the final decision of the District Court of Rotterdam in the Mines de Potasse d'Alsace case did not consider whether or not an equitable use was exceeded, in deciding upon the occurrence of serious or substantial harm, and in holding that the due diligence obligation of States to prevent serious or substantial harm was derived from the general principles of law recognized by civilized nations. ${ }^{19}$

In view of the foregoing, the essence of the no pollution harm principle shall be understood to be the obligation to prevent "factual harm".

\subsubsection{The essence of the equitable utilization principle: balancing of interests}

In seeking the essence of the equitable utilization principle, it is useful to examine both the commentary on the ILC Final Draft and the provisions of the 1997 Watercourses Convention.

From the commentary on Article 5 of the Final Draft on "equitable and reasonable utilization and participation", it can be concluded that the equitable utilization principle is required to realize the fundamental principle of "equality of rights" among watercourse States. ${ }^{20}$ This was also affirmed by the Permanent Court of International Justice (PCIJ) in its decision in the River Oder case of $1929,{ }^{21}$ which declared "perfect equality of all riparian

17 See 1988 ILC Report, op. cit. n. 15, at 27, para. 138. The term "harm" is maintained in Article 7 of the 1994 Final Draft as well as of the 1997 Watercourses Convention. See 1994 ILC Report, op. cit. n. 3, at 236; 36 ILM (1997) 706.

18 See 3 RIAA, at 1920-1933, 1966-1980. See also this author, op. cit. n. 1, Part 2, at 75-76.

19 See 15 NYIL (1984) at 480-481.

201994 ILC Report, op. cit. n. 3, at 221, para. (8).

${ }^{21}$ Case Relating to the Territorial Jurisdiction of the International Commission of the River Oder, The United Kingdom, Czechoslovakia, Denmark, France, Germany, Sweden/Poland (PCIJ, 10 September 1929), PCIJ Ser. A, No. 23. 
States". ${ }^{22}$ As to the concrete substance of the equitable utilization principle, Article 5, paragraph 1, of the 1997 Watercourses Convention provides as follows:

\begin{abstract}
Watercourse States shall in their respective territories utilize an international watercourse in an equitable and reasonable manner. In particular, an international watercourse shall be used and developed by watercourse States with a view to attaining optimal and sustainable utilization thereof and benefits therefrom, taking into account the interests of the watercourse States concerned, consistent with adequate protection of the watercourse.
\end{abstract}

Although cast in terms of an obligation, the provision also expresses the correlative entitlement, namely, the right of a watercourse State, within its territory, to a reasonable and equitable share, or portion, of the uses and benefits of an international watercourse. ${ }^{23}$ Therefore, the ILC regards the equitable utilization principle as the set of rights and obligations to use an international watercourse in an equitable and reasonable manner aiming at optimal and sustainable utilization thereof. ${ }^{24}$ The equitable utilization principle in this sense is supported overwhelmingly as a general rule of law for the determination of the rights and obligations of States in the field of non-navigational uses of international watercourses. ${ }^{25}$ This is also quite evident

\footnotetext{
${ }^{22}$ See id., at 26-27. The Court's view on "international fluvial law in general" seems to be sufficiently true of non-navigational uses which were not at issue in this case. See McCaffrey, Second Report, op. cit. n. 16, at 113-114; Jerome Lipper, "Equitable utilization", in Albert H. Garretson et al. (eds.), The law of international drainage basins (New York: Oceana Pub., 1967) 15 at 29. We should, however, remember that non-navigational uses are different from navigational uses in the following two respects: first, each riparian State can use the waters of an international watercourse only within the limits of its own territory; secondly, it is possible that the use of the waters of an international watercourse may change the quantity or quality of the waters in question. Lammers, op. cit. n. 2 , at 507.

231994 ILC Report, op. cit. n. 3, at 218, para. (2).

${ }^{24}$ In order to realize such an "equitable use", the principle of "equitable participation" is provided for in Article 5, paragraph 2, of the 1997 Watercourses Convention. The concept of the right of "equitable participation" had already been stated by the Court of Cassation of Italy in the 1939 River Roja case. See Societe Energie Electrique du Littoral Mediterraneen v. Compagnia Imprese Elettriche Liguri (Italy, Court of Cassation, 13 February 1939), 9 Annual Digest 120 at 121. On the other hand, as to the "obligation of participation", some members of the ILC expressed their concern about recognizing such a concept. See the Statement of Mr. Koroma, YILC, 1987, Vol. I, at 239, para. 35; Mr. Graefrath, id., at 240, para. 42; Mr. Barsegov, id., at 240, para. 44.

${ }^{25}$ See the Case Concerning the Gabcikovo-Nagymaros Project (Hungary/Slovakia), Judgment of the ICJ of 25 September 1997 [hereinafter, the Judgment], ICJ Rep. 1997, at 54, para. 78, at 56, para. 85; 1987 ILC Report, op. cit. n. 15, at 33, para. (10); Kurao Tsukikawa, "Some problems on the utilization of the waters of international rivers: with emphasis on diversion" (in Japanese), in International law in transition: essays in memory of Professor Shigejiro Tabata for his sixtieth birthday (in Japanese) (Tokyo: Yushindo, 1973) 103 at 126-131.
} 


\section{in the observations of governments ${ }^{26}$ on the Provisional Draft submitted to the Secretary-General of the United Nations. ${ }^{27}$}

${ }^{26}$ Governments were requested to submit their observations on the Provisional Draft to the SecretaryGeneral by 1 January 1993. See UN Doc., A/CN.4/447 (3 March 1993), at 3, para. 1. To this author's knowledge, at least twenty-one States submitted their own observations. See id. and its Add.1 (15 April 1993), Add.2 (18 May 1993), Add.3 (14 June 1993). Five States, that is, Denmark, Finland, Iceland, Norway and Sweden, submitted one observation as Nordic Countries. In order to clarify the situations of these States, we make the following classification. [1] [International Watercourse States] (a) Upper Riparian States: none. (b) Middle Riparian States: Nordic Countries, Costa Rica, Germany, Greece, Spain, Syrian Arab Republic, Turkey, The United States, Argentina, Canada, Chad, Hungary, The Netherlands, Switzerland <Non-UN Member State $>$, (Finland, Norway). (c) Lower Riparian States: Iraq, Poland, (Sweden). [2][Non International Watercourse States]: (Denmark, Iceland). Here we have classified as middle riparian States those falling into any of three categories below: i) those riparian States other than the uppermost or the lowest when the watercourse in question is situated among more than two States; ii) those riparian States becoming upper or lower according to different watercourses; iii) those riparian States of international lakes having no distinction between upper and lower. Moreover, when a State is to be classified as a middle riparian State as regards a certain watercourse, that State shall be so classified irrespective of being upper or lower as regards other watercourses. However, even if a State should be classified as a middle riparian State, that State is, out of respect for its own will, classified as an upper or a lower riparian State when it explicitly so claims. Consequently, Poland is classified as a lower riparian State though it should be classified as a middle riparian State. See A/CN.4/447/Add.1, at 10. Nordic Countries are classified as middle riparian States because there are middle riparian States among them. In order to classify upper, middle and lower riparian States of international watercourses as well as non-international watercourse States, we referred to the following. List of first order river basins shared by two or more countries, in Technical and economic aspects of international river basin development: report of the Secretary-General, UN Doc., E/C.7/35 (27 October 1972), Annex I, at 1-12. According to this, only one sixth of the States of the world are non-international watercourse States. Id., at 9 .

27 See for Germany, UN Doc., A/CN.4/447, at 20; Greece, id., at 23; The United States, id., at 40; Switzerland, id., at 46; Canada, A/CN.4/447/Add.1, at 4; Poland, id., at 10; Hungary, A/CN.4/447 /Add.2, at 5. Moreover, if we review the remarks of the States in the sixth committee of the General Assembly of the United Nations in the year 1987, when Articles 5 and 6 (Articles 6 and 7 at that time) of the Provisional Draft concerning the equitable utilization principle were adopted, we can confirm wide support for that principle. Besides the twenty-one States listed in the above note, there are at least following nineteen States clearly supporting that principle: [1][International Watercourse States] (a) Upper Riparian States: none. (b) Middle Riparian States: Mexico, Ireland, Israel, Venezuela, United Republic of Tanzania, Sudan, Chile, Austria, Ghana, Zambia, India. See for Mexico, A/C.6/42/SR.36, at 2, para. 3; Ireland, SR.38, at 14, para. 64; Israel, SR.45, at 17, para. 75; Venezuela, SR.46, at 4, para. 10; United Republic of Tanzania, id., at 17, paras. 86-87; Sudan, SR. 47 , at 11, para. 58; Chile, id., at 21, para. 104; Austria, SR.48, at 6, para. 23; Ghana, SR. 49, at 3, para. 8; Zambia, id., at 5, para. 17; India, id., at 6, para. 22. (c) Lower Riparian States: Italy, Egypt, Bangladesh, Jordan. See for Italy, SR.38, at 8, para. 34; Egypt, SR.40, at 4, para. 14; Bangladesh, id., at 8, para. 40; Jordan, SR. 44, at 4, paras. 12-13. [2][Non International Watercourse States]: Qatar, Jamaica, New Zealand, Bahrain. See for Qatar, SR.35, at 16, para. 59; Jamaica, SR.41, at 8, para.28; New Zealand, SR.43, at 23, para. 105; Bahrain, SR.47, at 9, para. 42. However, the German Democratic Republic, France and the Lao People's Democratic Republic, all middle riparian States, were sceptical about that principle. Brazil was concerned about the increase of harm by the application of that principle; other three States worried that the concept of "shared natural resources" 
All other States that did not directly support the equitable utilization principle made their observations on the premise that the principle in question existed. ${ }^{28}$ Reflecting the support of States for the principle, Articles 5 and 6 of the Provisional Draft were submitted to the Drafting Committee without modification in the second reading at the session of 1993, and were adopted in that Committee at the same session. ${ }^{29}$

What, then, is the essence of the equitable utilization principle? Considering that "factors relevant to equitable and reasonable utilization" are listed in Article 6, paragraph 1, of the 1997 Watercourses Convention, ${ }^{30}$ and that the question as to whether or not an equitable utilization be achieved is decided by balancing these factors, the essence of the principle is thought to be in the balancing of interests. ${ }^{31}$ In fact, the decisions of international courts and tribunals as well as domestic courts, which are said to have referred to the principle, have held that such balancing of interests should be made. For example, in the River Oder case the PCIJ referred to the need to fulfil "the requirements of justice and the considerations of utility". ${ }^{32}$ In the Lake Lanoux case of 1957, the Arbitral Tribunal held that there existed "the obligation to take into consideration the interests" of other States in the light of "current international practice" and "the rules of good faith". ${ }^{33}$ Moreover, in the Donauversinkung case, the Constitutional Court of Germany (Staatsgerichtshof) held in 1927 that the interests of riparian States of an international river had to "be weighed in an equitable manner against one another", and that also to be considered was "not only the absolute injury caused to the

underlying that principle would derogate from their own sovereignty. Nevertheless, Brazil, the German Democratic Republic and France suggested that they were ready to accept that principle if such fear could be wiped away. See for Brazil, SR.36, at 6-7, paras. 22-24; the German Democratic Republic, SR.43, at 3, para.7; France, SR.45, at 6, para. 22-24; the Lao People's Democratic Republic, SR.46, at 9, para. 33.

28 See UN Doc., A/CN/4/447, and its Add.1-3.

291993 ILC Report, UN Doc., GAOR, Forty-Eighth Session, Supp. No. 10 (A/48/10), at 217. The Final Draft and the 1997 Watercourses Convention see no fundamental change. See 1994 ILC Report, op. cit. n. 3, at 218, 231; 36 ILM (1997) 705-706.

${ }^{30}$ The factors listed in Article 6, paragraph 1, of the 1997 Watercourses Convention are as follows: (a)geographic, hydrographic, hydrological, climatic, ecological and other factors of a natural character; (b)the social and economic needs of the watercourse States concerned; (c)the population dependent on the watercourse in each watercourse State; (d)the effects of the use or uses of the watercourses in one watercourse State on other watercourse States; (e)existing and potential uses of the watercourse; (f)conservation, protection, development and economy of use of the water resources of the watercourse and the costs of measures taken to that effect; (g)the availability of alternatives, of corresponding value, to a particular planned or existing use. 36 ILM 706 (1997). These factors are not exhaustive but indicative, and no priority or weight is assigned to them. 1994 ILC Report, op. cit. n. 3, at 232, para. (3).

31 See Handl, op. cit. n. 5, at 188-189, 194.

32 PCIJ Ser. A, No. 23, at 27.

3312 RIAA, at 315. 
neighbouring State, but also the relation of the advantage gained by one to the injury caused to the other". 34

\subsection{The relationship between the Equitable Utilization principle and the No Pollution Harm principle highlighted}

It is said that the equitable utilization principle, the essence of which lies in the balancing of interests, originated as a principle on the use of water that involves the change of its quantity. ${ }^{35}$ Therefore, the question must be asked whether that principle also governs the use of water containing pollutants. If the answer to that question is negative, there will be no room to call into question the relationship between the equitable utilization principle and the no pollution harm principle.

The International Law Association has adopted the position that the equitable utilization principle also deals with water use where pollution is involved. Article IV of the "Helsinki Rules on the Use of the Waters of International Rivers" of $1966^{36}$ stipulates that the equitable utilization principle is a fundamental principle governing the use of water of international rivers. In addition, the obligation to prevent pollution causing substantial injury, i.e., a higher level of harm ${ }^{37}$ to another co-basin State, stipulated in Article $\mathrm{X}$ of the said Rules, is meant to be consistent with the equitable utilization principle. The commentary on Article X states that "uses of the waters by a basin State that cause pollution resulting in injury in a co-basin State must be considered from the overall perspective of what constitutes an equitable utilization". ${ }^{38}$

Similarly, Article 1 of the "Montreal Rules on Water Pollution in an International Drainage Basin" of $1982^{39}$ lays down the obligation to prevent pollution causing substantial injury to another State, "consistent with the Helsinki Rules on the equitable utilization of the waters on an international

\footnotetext{
${ }^{34}$ The Donauversinkung case, Wurttemberg and Prussia v. Baden (German Staatsgerichtshof, 18 June 1927), 4 Annual Digest 128 at 131.

${ }_{35}$ Robert D. Hayton, "The present state of research carried out by the English-speaking section of the Centre for Studies and Research", in Centre for Studies and Research in International Law and International Relations of the Hague Academy of International Law, Rights and duties of riparian states of international rivers (Dordrecht: Nijhoff, 1991) 59 at 70. Both the Lake Lanoux and the Donauversinkung cases are concerned with the water use involving the change of water quantity.

36 ILA, Report of the fifty-second conference held at Helsinki (1966) at 486.

37 Generally, an injury is considered "substantial" if it materially interferes with or prevents a reasonable use of water. $I d$., at 500 .

38 Id., at 499.

${ }^{39}$ ILA, Report of the sixtieth conference held at Montreal (1982) at 535 [hereinafter, 1982 Montreal Report]. See also Article 1 of Draft Articles on the Relationship between Water, Other Natural Resources and the Environment, ILA, Report of the fifty-ninth conference held at Belgrade (1980) at $374-375$.
} 
drainage basin". The commentary on Article 1 of the Montreal Rules lists the reasons of the equitable utilization principle being regarded as covering also the water use involving pollution, as follows: (1) "the activity that produces water pollution is itself a utilization of the water resource that may be reasonable and equitable in the particular circumstances"; (2) "the equitable utilization principle provides a desirable flexibility in the disposition of disputes concerning the complex questions raised in cases of water pollution" ${ }^{40}$

The Institut de droit international (Institute of International Law) [hereinafter, the Institut] does not exclude a priori the possibility of the equitable utilization principle governing water use involving pollution, as is shown by the reference to "equitable utilization" in the preamble of the resolution on "Pollution of Rivers and Lakes and International Law" [hereinafter, the Athens Resolution]. ${ }^{41}$

Finally, we shall examine the discussions in the ILC on the topic of international watercourses. Between Schwebel and Evensen, the second and third Special Rapporteurs on this topic, there was no difference of opinion on the argument that the equitable utilization principle also governs the water use involving pollution. For example, in draft Article 7, paragraph 1, subparagraphs (a)(vii) and (b), of Schwebel's third report ${ }^{42}$ as well as in draft Article 8, paragraph 1, sub-paragraphs (g) and (h), of the first report, ${ }^{43}$ and draft Article 8, paragraph 1, sub-paragraphs (h) and (i), of the second report ${ }^{44}$ of Evensen, "pollution" and "adverse effects" were included in the factors to determine "equitable use". In addition, in draft Article 10, paragraph 3, of Schwebel's third report (as well as in draft Article 23, paragraph 1, of the first and second reports of Evensen), the reference to "equitable use" was made in relation to the obligation to prevent pollution causing appreciable harm. Moreover, in draft Article 10, paragraph 4, of Schwebel's third report (as well as in draft Article 23, paragraph 2, of the first and second reports of Evensen) the obligation to prevent pollution causing harm on a less than appreciable level was stipulated on condition that the affected State defrays a part of the costs necessary to abate pollution; ${ }^{45}$ there was the consideration of the equitable utilization principle in the background whenever such a condition was introduced. ${ }^{46}$

40 ILA, 1982 Montreal Report, id., at 536.

4158 Annuaire Part 2 (1979) at 196-203.

${ }^{42}$ Schwebel, Third Report, YILC, 1982, Vol. II, Part One, at 65.

43 Jens Evensen, First Report, YILC, 1983, Vol. II, Part One, at 155.

44 Evensen, Second Report, YILC, 1984, Vol. II, Part One, at 101.

${ }^{45}$ In Evensen's Draft, however, the watercourse States concerned are only obliged to consult for the defrayment of the cost for pollution abatement.

${ }^{46}$ Schwebel, Third Report, op. cit. n. 42, at 149, paras. 324-325. 
However, in draft Article 16, paragraph 2, of McCaffrey's fourth report, ${ }^{47}$ stipulating the obligation to prevent pollution causing appreciable harm, there was no reference to "equitable use"; nor was there a reference to "equitable use" either in the Drafting Committee's draft Article 23, paragraph $2{ }^{48}$ or in Article 21, paragraph 2, of the Provisional Draft, both of which found their origin in the paragraph proposed by McCaffrey. Besides, the obligation to prevent harm on a less than appreciable level did not figure as an independent article in McCaffrey's fourth report ${ }^{49}$ nor in the 1997 Watercourses Convention. Consequently, there was no clear description in that report of the idea that the affected State would defray part of the costs to abate the pollution. Moreover, in the Drafting Committee's draft Article 7, ${ }^{50}$ elaborated on the basis of draft Article 8 of Evensen's second report, "pollution" and "adverse effects" were deleted from the factors to determine "equitable use", and that position was also followed in Article 6 of the Provisional and Final Drafts, as well as in the 1997 Watercourses Convention. ${ }^{51}$

The above-mentioned facts seem to deny the equitable utilization principle a role in the matter of water use involving pollution. However, in McCaffrey's fourth report ${ }^{52}$ it was clearly recognized that the principle did govern the topic. In fact, draft Article 17, paragraph 2, of that report, dealing with the protection of the marine environment, ${ }^{53}$ provided that watercourse States should take measures to protect the marine environment "on an equitable basis". In Article 23 of the Provisional and Final Drafts, based on the aforementioned paragraph, this phrase was deleted for the purpose of simplification,${ }^{54}$ but the commentary emphasizes that "joint, cooperative action"

47 McCaffrey, Fourth Report, op. cit. n. 2, at 205.

48 YILC, 1990, Vol. I, at 282, para. 26.

49 However, draft Article 17, paragraph 1, of McCaffrey's fourth report, Article 22 of the Drafting Committee's Draft and Article 20 of the Provisional and Final Drafts, all concerning protection of the environment of international watercourse[s] [systems], seem to include such an obligation. See 1990 ILC Report, UN Doc., GAOR Forty-Fifth Session, Supp. No. 10 (A/45/10), at 163, para. (6); 1994 ILC Report, op. cit. n. 3, at 293, para. (6); 36 ILM 710 (1997).

50 YILC, 1987, Vol. I, at 206, para. 1.

51 Professor Caflisch thinks that the deletion, from the Drafting Committee's Draft and the Provisional Draft, of factors such as "pollution" and "adverse effect", formerly included among the factors to determine "equitable use", is the logical consequence of the subordination of equitable utilization principle to the obligation not to cause appreciable (pollution) harm. Lucius Caflisch, "Sic utere tuo ut alienum non laedas: regle prioritaire ou element servant a mesurer le droit de participation equitable et raisonnable a l'utilisation d'un cours d'eau international?", in Alexander von Ziegler \& Thomas Burckhardt (eds.), Internationales Recht auf See und Binnengewassern, Festschrift fur Walter Müller (Zurich: Schulthess, 1993) 27 at 36.

52 Op. cit. n. 2, at 238, para. 5, at 241-242, paras. 12-16.

53 The paragraph in question had been elaborated especially for pollution. See YILC, 1988, Vol.

II, Part One, at 244, para. (4).

54 The term in question had been deleted at the stage of the elaboration of Article 25 of the Drafting Committee's Draft. See YILC, 1990, Vol. I, at 288, para. 7. 
should be taken "on an equitable basis". ${ }^{55}$ In addition, the commentary on Article 20 concerning "protection and preservation of ecosystems" and that on the aforementioned Article 21, paragraph 2 of the Provisional and Final Drafts emphasize the same meaning. ${ }^{56}$ Moreover, while there were some arguments about how to consider the relationship between the equitable utilization principle and the obligation not to cause appreciable (pollution) harm, the members of the ILC ${ }^{57}$ as well as the governments ${ }^{58}$ started from the premise that the equitable utilization principle also applied to water use entailing pollution.

The above examination thus leads us to the conclusion that the relevance of the equitable utilization principle for the use of water entailing pollution is now generally recognized. Such a conclusion can also be drawn from the Trail Smelter arbitral award, ${ }^{59}$ which is an outstanding precedent in the field of transfrontier pollution. ${ }^{60}$ In its final decision of 1941 the Arbitral Tribunal carried out the balancing of interests by considering the "equitable use" by the Parties, while admitting the liability of Canada for having violated the obligation, under international law, to prevent, with due diligence, serious transfrontier pollution harm. ${ }^{61}$ It did so during the process of arriving at the above-mentioned conclusion $^{62}$ as well as when it subsequently ordered a

\footnotetext{
551990 ILC Report, op. cit. n. 49, at 170-171, para. (3); 1994 ILC Report, op. cit. n. 3, at 299, para. (3).

561990 ILC Report, op. cit. n. 49, at 150, para. (4), 162, para. (5); 1994 ILC Report, op. cit. n. 3, at 282, para. (4), at 292-293, para. (5). These commentaries see the obligation to "prevent, reduce and control pollution jointly" and the obligation to "take steps to harmonize...policies" within the sphere of the equitable utilization principle.

57 See the Statement of Mr. Calero Rodrigues, YILC, 1988, Vol. I, at 127, para. 5; Mr. Beesley, $i d$., at 128, para. 15; Mr. Bennouna, id., at 134, para. 6; Mr. Mahiou, id., at 139, para. 2; Mr. Shi, $i d$., at 141, para. 17; Mr. Al-Khasawnhe, id., at 147, para. 18; Mr. Sreenivasa Rao, id., at 151, para. 46; Mr. Al-Qaysi, id., at 158, para. 32.

58 See the Comments from Nordic Countries, UN Doc., A/CN.4/ 447, at 27; from the United States, $i d$., at 40; from Switzerland, id., at 51, 53; from Canada, A/CN.4/447/Add.1, at 5; from Poland, id., at 10; from the Netherlands, A/CN.4/447/Add.3, at 9. See also the Statement of Mr. Crawford (Australia), A/C.6/43/SR.30, at 4, para. 10; Mr. Park (Republic of Korea), SR.31, at 24, para. 109. 593 RIAA, at 1907.

60 See Robert Q. Quentin-Baxter, Second report on international liability for injurious consequences arising out of acts not prohibited by international law [hereinafter, Second Report on Liability], YILC, 1981, Vol. II, Part One, 103, at 110, para. 27; Third Report on Liability, YILC, 1982, Vol. II, Part One, 51, at 54, para. 14.

61 See 3 RIAA, at 1965-1966.

62 First, the Tribunal emphasized "an equal interest" between two States. See id., at 1938. Secondly, the Tribunal referred to the need for "just solution" balancing the interests of Canadian industry and the United States agriculture, and also referred to the characteristic of the regime for it. See id., at 1939. Thirdly, the Tribunal pointed out that "equity" was also taken into account in the decisions of the United States Supreme Court concerning pollution, which were invoked to show the existence of the no pollution harm principle under international law. See id., at 1965.
} 
prevention régime. ${ }^{63}$ It should be admitted that the decision was somehow influenced by Article 4 of the compromis between the parties, providing that "the Tribunal shall give consideration to the desire of the high contracting parties to reach a solution just to all parties concerned". ${ }^{64}$ Yet the judgment is certainly relevant for the case of pollution of international watercourses in view of the similarity between the cases of water pollution and of air pollution. ${ }^{65}$

On the other hand, it is widely accepted that "the activity that produces water pollution is itself a utilization of the water resource". The ILA has already pointed this out. From a theoretical point of view there is, consequently, no reason to exclude, a priori, the applicability of the equitable utilization principle to the matter of water use entailing pollution, even though one might suppose that the principle would be subject to some restrictions.

As discussed earlier, if the applicability of the equitable utilization principle to the issue of water use entailing pollution be assumed, the riparian States would have the obligation to "share equitably" when taking measures to prevent pollution. This would easily be recognized, since the ILC employs the equitable utilization principle when emphasizing the obligation of "equitable participation" ${ }^{66}$ This requires States to take joint, co-operative measures to prevent pollution. In addition, as is shown by the Trail Smelter case, it is necessary to consider the various circumstances of the States concerned when deciding on the regime to prevent or rescind the harm, as far as the prohibited level of pollution harm has not been reached. It is, of course, controversial whether or not the equitable utilization principle includes the determination of that level of pollution harm. In relevant cases the activities are to a large extent economically or socially important for the watercourse State in question (Article 6, paragraph 1(b), of the 1997 Watercourses Convention). Alternatively, the activities may generate benefits that exceed the costs of conservation measures (Article 6, paragraph 1(f), thereof). In such cases it may be feasible that, on the basis of the balancing of interests, the occurrence of a certain level of "factual harm" is allowed by the equitable utilization principle, without any conditions or, at the most, conditions on the payment of compensation. ${ }^{67}$ In such a situation, the relationship between

\footnotetext{
${ }^{63}$ First, the Tribunal excluded a very strict prevention régime suggested by the United States, by which a prefixed sum would be due whenever the concentrations recorded would exceed a certain intensity. See id., at 1974. Secondly, the Tribunal ordered Canada to implement a régime which would "probably remove the causes of the present controversy and ... probably result in preventing any damage of a material nature occurring in the State of Washington in the future." See id., at 1980. Thirdly, the Tribunal admitted Canada's liability for such damage as occurring notwithstanding the maintenance of the regime in question. See id.

${ }^{64}$ See id., at 1908.

${ }^{65}$ Id., at 1963; Ando, op. cit. n. 2, at 334; Tsukikawa, op. cit. n. 2, at 613.

${ }^{66}$ See op. cit. n. 24.

${ }^{67}$ See Article 5 paragraph 2 (j) of the ILA Helsinki Rules.
} 
the equitable utilization principle and the no pollution harm principle becomes highlighted.

There are some scholars, such as Lammers, ${ }^{68}$ who deny a priori the determination of the level of pollution harm to be prevented by the equitable utilization principle. He points out that if such a determination is allowed, the standard adopted would become ambiguous because of the need to take into account a great number of factors ${ }^{69}$ However, it is possible to envisage the activity in question to be prohibited because it exceeds the "equitable use", even in the case of pollution causing harm below the level of "harm to be prevented". ${ }^{70}$ The problem thus lies in whether or not the no pollution harm principle is "relaxed" by the equitable utilization principle. The fact that the Institut, although referring to the equitable utilization principle in the preamble of its Athens Resolution, evaded any reference to the said principle in the operative articles of the resolution ${ }^{71}$ could be seen as a manifestation of its concern about such "relaxation". On the other hand, there are

\footnotetext{
68 Lammers, op. cit. n. 13, at 162-163.

69 "The mitigated-no-substantial-harm principle" supported by Dr. Lammers also takes equity into account by considering the following three elements: 1) the protection to be given to exceptionally sensitive interests; 2 ) the nature of the obligation of States to prevent or abate transfrontier pollution, this obligation being a due care or due diligence obligation; 3) the fact that in exceptional cases the obligation to prevent or abate transfrontier pollution causing substantial harm to other States is to be replaced by an obligation to pay compensation for the harm caused, viz., when there clearly exists a high disproportion between, on the one hand, the technical or socio-economic costs involved in preventing or abating the pollution and, on the other hand, the substantial harm caused to other States or the benefit gained by those States if the pollution were to be reduced to an insignificant level. Id., at 156. However, it should be remembered that this principle is, according to him, different from the principle of equitable utilization of "shared natural resources" in that the interests to be considered in the former principle are limited while the latter principle allows unlimited balancing of interests. Id., at 162. Moreover, it should also be remembered that he uses the term "substantial harm" as indicating a relatively lower level of harm, namely appreciable (=significant) harm as used in the ILC. See Lammers, op. cit. n. 2, at 381.

${ }^{70}$ In such a case, it will be a matter of "equitable apportionment" of the pollution emission limit. See Magraw et al., Fourth Report on LDAP, op. cit. n. 12, at 29-36. However, it should be remembered that even here the obligation to prevent pollution contained in Article 20 of the Provisional and Final Drafts as well as in Article 20 of the 1997 Watercourses Convention still remains to be operative. See op. cit. n. 49.

${ }^{71}$ Although Article 2 of the Athens Resolution provides for the obligation to prevent pollution of international watercourses, there is no reference to the equitable utilization principle in contrast with the ILA resolutions. Moreover, the Athens Resolution has no separate article providing for the equitable utilization principle, unlike Article 3 of the Institut's Resolution on the Use of International Non-Maritime Waters of 1961 (the Salzburg Resolution) emphasizing the settlement "on the basis of equity". See 49 Annuaire Part 2 (1961) at 370-373. The reference to the equitable utilization principle in the preamble of the Athens Resolution merely intended to suggest the relativity of the concept of pollution. See 58 Annuaire Part 2 (1979) at 110, Part 1 (1979) at 334-335. Article 2 of the Athens Resolution says nothing about the level of pollution harm to be prevented. This is because, in the view of the Institut, the factual tolerance of a certain degree of pollution was due to mere acquiescence, not due to right. $I d$, at 343-344.
} 
also strong arguments in support of such "relaxation", as will be seen in the next Part of this paper.

\section{ARGUMENTS FOR THE "RELAXATION" OF THE NO POLLUTION HARM PRINCIPLE BY THE EQUITABLE UTILIZATION PRINCIPLE}

\subsection{A survey of academic views}

As has already been seen, the ILA has consistently taken the position that the equitable utilization principle also applies to water use entailing pollution. To be noted is that the ILA recognizes that a higher level of harm to be prevented, namely "substantial injury", is raised even further by the equitable utilization principle. This can be concluded from Article 1 of the "Complementary Rules Applicable to International Water Resources", ${ }^{72}$ which prescribes the obligation to prevent "substantial injury" to other States, "provided that the application of the principle of equitable utilization ... does not justify an exception in a particular case". ${ }^{73}$

Caflisch is among those scholars who also advocate the "relaxation" of the no pollution harm principle. In order to understand his arguments, it will be useful to examine his criticism to McCaffrey's view which supports the position of the Provisional Draft and rejects such "relaxation". The Provisional Draft does not admit, unless there is a watercourse agreement prescribing otherwise, any "relaxation" by the equitable utilization principle and demands strict application of the obligation not to cause appreciable harm of any kind, i.e., not restricted to pollution. Professor McCaffrey supports this approach for the following three reasons: first, the ILC's approach affords a measure of protection to a weaker State that has suffered harm; secondly, it is far simpler to determine whether the no (pollution) harm rule has been breached than to determine a breach of the obligation of equitable utilization; thirdly, the no harm rule is preferable in cases involving pollution and other threats to the environment. ${ }^{74}$ With regard to these arguments, Professor Caflisch makes the following criticisms: as regards the first point, the ILC's approach is apt to concede privileges to developed countries which are existent users; in respect of the second point, notions such as "serious" or "appreciable" harm are much more ambiguous than the "equitable utilization" principle; concerning the third point, certain circumstances may require toleration of appreciable harm in order to achieve the optimal use of a watercourse. In addition, Caflisch criticizes the approach of the Provisional Draft for the

\footnotetext{
2 ILA, Report of the sixty-second conference held at Seoul (1986) at 275.

Id., at 281-282.

${ }^{74}$ McCaffrey, "The law of international watercourses: some recent developments and unanswered questions”, 17 Den. J. Int'l L. \& Pol'y (1989) 505 at 510.
} 
following four reasons: first, the approach deviates from contemporary State practice; secondly, the approach results in the protection of existent activities to a much larger extent than new activities; thirdly, it is not really something for a framework treaty to prescribe the no pollution harm principle; and lastly, the approach blocks new activities. Especially with a view to the protection of the environment he proposes the following two solutions: relinquishment of "relaxation" of the no pollution harm principle only in case of pollution that is [in French] "importante" or "massive"; and the adoption of the "mitigated no-substantial-harm principle" 75 supported by Lammers. However, Caflisch rejects the first solution despite the advantage of its simplicity, because of the ambiguity of notions like "importante" and "massive" as well as because of its incompatibility with the equitable utilization principle: this principle takes into account all pertinent factors while the proposed solution takes up the degree of harm as the sole object of consideration. In conclusion, Caflisch proposes the application of the no harm principle as an independent provision only with regard to environmental protection, and making the principle subject to the equitable utilization principle by adopting the "mitigated no-substantial-harm principle". 76

It follows from the foregoing that Caflisch advocates a reversion to a position that allows the "relaxation" of the no (pollution) harm principle by application of the equitable utilization principle, mainly on the basis of the following arguments: first, the approach of the Provisional Draft not only implies a privileged position for developed countries (existent users) but also deviates from the contemporary State practice; secondly, the determination of a threshold of harm to be prevented by such notions as "importante" or "massive" are ambiguous. ${ }^{77}$ Meanwhile, he would allow activities involving transfrontier harm within the range of "equitable use", taking into consideration various factors, among which is the fact of whether or not the no pollution harm principle is being observed. ${ }^{78}$ It is true that he, too, admits, from the point of view of environmental protection, that a stricter standard, that is, the "mitigated no-substantial-harm principle", should be applied in the case of environmental harm, but that would not change the applicability of the equitable utilization principle in determining the level of harm to be prevented. The "mitigated no-substantial-harm principle" would in fact remain

\footnotetext{
75 See op. cit. n. 69.

${ }^{76}$ Caflisch, op. cit. n. 51, at 42-47. While the observation of Switzerland to the Provisional Draft adopts Caflisch's view, it does not exclude the first solution he proposed. See UN Doc., A/CN.4/447, at 51-53.

77 Caflisch also argues that it is necessary to consider the requirement of "the optimal use of a watercourse" as well as the inadequacy to insert the no (pollution) harm principle into a framework treaty. However, these arguments are not persuasive because the former requirement might conversely need the rejection of the "relaxation" of the no (pollution) harm principle, and because the latter seems to be a matter of policy consideration.

78 Caflisch, op. cit. n. 51, at 47.
} 
subordinated to the equitable utilization principle. ${ }^{79}$ This is contrary to Lammers's reasoning when he proposed the "mitigated no-substantial-harm principle" in order to avoid a determination by applying the equitable utilization principle. However, if, as Caflisch argues, the "mitigated no-substantial-harm principle" is regarded as perfectly compatible with the equitable utilization principle in the sense that the former principle conciliates economic needs with ecological imperatives,${ }^{80}$ we would have to question the very validity of the approach by which the determination of the level of harm to be prevented in case of pollution harm takes place by using the "mitigated no-substantial-harm principle”.

\subsection{The background of the arguments: protection of the interests of upper riparian developing countries as beginning users}

In arguing in favour of "relaxation" of the no (pollution) harm principle by the application of the equitable utilization principle as composed of various factors, the factor most emphasized by Caflisch is the need to protect the interests of developing countries as beginning users. One may suspect that, in the background of his suggestion to adopt the "mitigated no-substantialharm principle" instead of bluntly rejecting "relaxation", even in the case of pollution harm, there is the consideration of alleviating the burden for developing countries by an obligation to pay compensation. This is allowed under the principle in question in case of a high disproportion between the costs to reduce pollution and the benefits gained by that reduction. ${ }^{81}$

It may be emphasized that resort is made to the equitable utilization principle in order to remedy inequitable consequences of the no (pollution) harm principle such as the fact that developed countries (usually lower riparian States), being existent users, are put into a more favourable position because developing countries (usually upper riparian States), being new users, inevitably cause harm. ${ }^{82}$ As a result, the desire to "relax" the no (pollution) harm principle by the equitable utilization principle would seem to be quite natural.

However, from the beginning there has been much opposition against the admission of a "double standard", which differentiates the pollution prevention standard between upper riparian developing countries and lower riparian developed countries by allowing such "relaxation". This became apparent during the drafting process of the 1979 Athens Resolution of the Institut.

79 Id., at $45,47$.

$80 \mathrm{Id}$, at 45 .

81 Loc. cit.

82 Id., at 42; McCaffrey, "The International Law Commission and its efforts to codify the international law of waterways", 47 ASDI (1990) 32 at 49-50; The Statement of Mr. McCaffrey, YILC, 1984, Vol. I, at 245, paras. 32, 34-35. The following States clearly supported such "relaxation" in their governmental observations to the 1994 Final Draft: Ethiopia, UN Doc., A/51/275, at 33-34; 
First, the Special Rapporteur, Professor Salmon, avoided a specification of the grounds in favour of the prohibition of environmental harm. He held the view that these grounds, including the equitable utilization principle, are not contrary to each other and could be harmonized. ${ }^{83}$ Many members of the Institut, however, were against recognizing the principle in question as a substantive principle because of the ensuing risk of [in French] "double pollution" or "légalisation de la pollution". ${ }^{84}$ Secondly, the Special Rapporteur regarded the obligation to prevent pollution of international watercourses as a due diligence obligation ${ }^{85}$ and suggested that the equitable utilization principle should be applied in judging the reasonableness of the due diligence in question. ${ }^{86}$ Consequently, the sentence "La vigilance doit étre adaptée aux circonstances et, en particulier, à l'état de développement des États en cause" was included in Article 3, paragraph 2, of the Draft Resolution. ${ }^{87}$

In the course of the deliberations, much criticism was aimed at the idea of taking account of the stage of development of a State. For example, Judge Oda expressed his concern over establishing a "principle of the double standard of norms" ${ }^{\text {"88 }}$; Professor Suy emphasized the necessity to submit all States to the same rules, ${ }^{89}$ and Professor Yasseen warned that the natural environment of developing countries would sooner or later also be exposed to real danger resulting from a double standard. ${ }^{90}$ Because of these critical observations, the reference to the state of development of a State was finally

Spain, id., at 45; Turkey, id., at 45; Switzerland, id., at 47 . The following States clearly objected to it: Hungary, id., at 34, 43; Greece, A/51/275/Add.2, at 7. The following States regretted the insufficient recognition of the "relaxation" by the 1997 Watercourses Convention when it was adopted at the United Nations General Assembly: Turkey, A/51/PV.99, at 5; Czech Republic, id., at 6; Slovakia, id., at 7; France, id., at 8; Ethiopia, id., at 9-10; Spain, id., at 12. Thus we can confirm that the States supporting the "relaxation" are, except for France, those which are situated on relatively upper positions of international watercourses and are economically less developed than lower riparian States.

8358 Annuaire Part 2 (1979) at 107.

8458 Annuaire Part 1 (1979) at 207-208, where it is stated as follows: "La théorie de l'utilisation équitable et son corollaire d'équilibre raisonnable des intérêts ont pour effet de considérer la pollution comme le résultat d'un usage du fleuve considéré sinon comme légitime du moins comme souhaitable .... En mettant en balance les intérêts de l'Etat d'aval et ceux d'amont on risque souvent d'aboutir à une double pollution et en tout cas à une légalisation de la pollution."

${ }^{85} I d$., at 217. Articles 1 and 2 of the Athens Draft Resolution expressly prescribed the term "une diligence raisonnable". Id., at 358-359. However, Article 2 of the Athens Resolution shows that this term was finally deleted. This deletion was carried out for harmonizing with the expression of Principle 21 of the Stockholm Declaration. Therefore, it does not mean that the concept of "due diligence" was denied. 58 Annuaire Part 2 (1979) at 121.

8658 Annuiare Part 1(1979) at 288.

87 Id., at 359.

8858 Annuiare Part 2 (1979) at 127-128.

89 Id., at 131.

90 Id., at 133. 
deleted ${ }^{91}$ and Article 3, paragraph 1, of the Athens Resolution in the end reads as follows: "States shall take and adapt to the circumstances all measures...." As we have seen, the Institut in fact rejected the equitable utilization principle as a means to raise the minimum level of harm to be prevented, and took a very negative stand regarding its invocation when judging the reasonableness of due diligence. However, since considerations of "equity" are already inherent in the concept of due diligence, ${ }^{92}$ and since the extent of actual presence of due diligence is determined by weighing various factors, it could be said that there was really no need to examine separately the question of a "double standard" of due diligence in assessing the impact of the equitable utilization principle on the no pollution harm principle. Actually, it may be said that a "double standard" is always applied in so far as the state of development of a State is taken into account when examining if the necessary resources and means were available in judging the absence or presence of due diligence. Therefore, the risk that pollution emanating from developing countries will increase is indeed becoming greater. The pollution prevention standard could nonetheless be decided in advance and objectively because it is necessary for the State of origin to exercise due diligence in accordance with at least its own national standard. ${ }^{33}$ On the contrary, if we allow a "double standard" in determining the level of harm to be prevented, it would become impossible to assess that level in advance and objectively, because of the need to consider the various circumstances on the part of the State of origin, such as the economic need for the activity in question. From this perspective the "relaxation" of the no pollution harm principle by the equitable utilization principle, including the argument of the "mitigated no-substantial-harm principle", is dangerous. If we give priority to "pollution prevention", we would be led strictly to apply the no pollution harm principle, which focuses merely on the "factual harm" suffered in the affected State. The issue of whether this is in accord with the positive law will be examined in the following Parts of this paper.

\section{DELIBERATIONS IN THE INTERNATIONAL LAW COMMISSION AND THE OBSERVATIONS OF GOVERNMENTS}

The rejection of the "relaxation" of the no pollution harm principle by the equitable utilization principle received wide support among the members of the ILC as well as from the governments during the deliberations on the Draft Articles.

The second Special Rapporteur, Schwebel, admitted that the level of harm to be prevented, that is, appreciable harm, was increased by the equitable

91 Id., at 134.

92 See McCaffrey, Fourth Report, op. cit. n. 2, at 241, paras. (14).

93 See this author, op. cit. n. 1, Part 2, at 64-72. 
utilization principle. $^{94}$ Later, however, the ILC consistently supported the very strict position of not allowing such a rise subject to a contrary agreement at least so far as harm by pollution is concerned. The typical position was that taken by the third Special Rapporteur Evensen: in draft Article 9 of his first and second reports, ${ }^{95}$ which contained the obligation to prevent appreciable harm, the exception based on the equitable utilization principle had been deleted; in draft Article 23, paragraph 1, the phrase that pollution shall be prevented "consistent with the equitable utilization principle" had also been deleted. No longer could any activity causing appreciable harm be regarded as "equitable use". 96 Opinions varied on this stand among other members of the ILC. ${ }^{97}$

The fourth Special Rapporteur, McCaffrey, while admitting that the level of harm to be prevented, namely appreciable harm, may indeed be raised by the equitable utilization principle in the case of harm by causes other than pollution, did not allow such a rise in the case of harm by pollution. In the case of harm other than by pollution, ${ }^{98}$ he proposed three ways to harmonize the obligation to prevent appreciable harm with the equitable utilization principle. ${ }^{99}$ Irrespective of the means chosen, however, he allowed the occurrence of appreciable harm provided it falls within the range of "an equitable use". There were opinions for and against this approach among the members of the ILC. ${ }^{100}$

94 See Schwebel, Third Report, op. cit. n. 42, at 148, para. 323. It seems that he regarded the obligation not to cause appreciable harm as a due diligence obligation. See id., at 95, para. 118, at 101 , para. 144 .

95 Evensen, First Report, op. cit. n. 43, at 155; Second Report, op. cit. n. 44, at 101.

961983 ILC Report, YILC, 1983, Vol. II, Part Two, at 72, para. 246.

97 See Caflisch, op. cit. n. 51, at 33-35. Mr. Barboza was in favour. See YILC, 1983, Vol. I, at 228, para. 25. Mr. Quentin- Baxter, Mr. Lacleta Munoz and Mr. McCaffrey were against. See YILC, 1984, Vol. I, at 251, para. 25; at 269, para. 34; at 245, para. 32.

98 See McCaffrey, Second Report, op. cit. n. 16, at 133-134, paras. 179-184. McCaffrey seemingly regarded the obligation not to cause appreciable harm prescribed in draft Article 9 of Evensen's second report as a due diligence obligation. See McCaffrey, Fourth Report, op. cit. n. 2, at 241, para. (14), footnote 238 .

99 One way is to replace the words "appreciable harm to the rights or interests of [other watercourse States]" in the text of Article 9 of Evensen's second report by "injuries to". A second way is to replace the reference to causing appreciable harm by a reference to a State exceeding its equitable share, or depriving another State of its equitable share. A third way is to make express reference to the duty to refrain from causing harm, but to make it clear that, even if a State's utilization of a watercourse does cause harm, the duty is not violated so long as the utilization is an equitable one vis-à-vis the other State(s). McCaffrey himself believed the third alternative to be the best because it is more precise than the other two.

100 See Caflisch, op. cit. n. 51, at 35. First, Mr. Calero Rodriguez and Mr. Barboza insisted on rejecting McCaffrey's proposal and maintaining the provision of draft Article 9 of Evensen's second report. However, between these two some difference can be found. Calero Rodriguez did not admit that the level of harm to be prevented, namely appreciable harm, was raised by the equitable utilization principle. This is shown by his remarks that "equitable use" is a use that causes no harm. 
As to pollution harm, McCaffrey's line of reasoning was as follows. There are strong arguments in favour of treating the effects of pollution differently from other kinds of harm. In the light of the need to protect the environment so as to enable sustainable development and to preserve the earth for future generations, water uses that cause appreciable pollution harm to other watercourse States and to the environment could be regarded as being inequitable and unreasonable per se. In the case of pollution the ILC should adopt a rule of "no appreciable pollution harm" that is not qualified by the principle of equitable and reasonable utilization, without prejudice to any decision the ILC may take with regard to whether there should be an equitable-use exception to the general rule of "no appreciable harm" contained in draft Article 9. Even if such a rule of "no appreciable harm" were adopted, at least in relation to the pollution of international watercourses, it would still be mitigated to some extent by the manner in which States apply the principle of "due diligence". In so far as this element introduces considerations of "equity" when applying the rule of "no appreciable harm", the outcome could be the same as subjecting the rule to the doctrine of equitable utilization. ${ }^{101}$ Reflecting this reasoning, draft Article 16, paragraph 2, of his fourth report ${ }^{102}$ did not contain a limitation by the equitable utilization principle; nor was the relaxing role of due diligence specified in the proposed article. It was to be referred to only in the comment on the article. ${ }^{103}$

As no one uttered a rejection of McCaffrey's opinion that the ILC should, at least so far as pollution is concerned, reject the raising of the level of harm to be prevented, namely appreciable harm, by the equitable utilization principle, ${ }^{104}$ it seems that the approach had received wide support from among the other members of the ILC. Yet there were those who, as did Mr. Calero

To the contrary, Barboza, like McCaffrey, allowed such a rise. This is shown by his remarks that if the use in question falls within the equitable share of uses, it is impossible to speak of harm. He simply objected to using the term "harm" in speaking of "equitable use", because "harm" had a negative connotation. See YILC, 1986, Vol. I, at 224-225, paras. 8-10; at 226, para. 24. Secondly, Mr. Malek, reserved his position in this respect. However, he does not seem to have allowed such a rise because he stated that any use, however equitable, that caused or was likely to cause appreciable harm to another State would be regarded as wrongful. See id., at 237, para. 9, at 238, paras. 16-17. Thirdly, some supported any one of the ways proposed by McCaffrey: for a supporter of either the first or second ways, see the Statement of Mr. Roucounas, id., at 234, para. 35; for supporters of the third way, see the Statement of Mr. Flitan, id., at 222, para. 6; Mr. Mahiou, id., at 223, paras. 15- 16; Mr. El Rasheed Mohamed Ahmed, id., at 229, para. 42; Mr. Balanda, id., at 232, para. 13; Mr. Yankov, id., at 239, para. 23.

101 See McCaffrey, Fourth Report, op. cit. n. 2, at 241, paras. (12)-(14).

102 Loc. cit.

103 Id., at 238-241, paras. (6)-(11).

104 See the Statement of Mr. McCaffrey, YILC, 1988, Vol. I, at 164, para. 56. Many members expressly supported his opinion. See the Statement of Mr. Mahiou, id., at 139, para. 2; Mr. Shi, $i d$., at 141, para. 17; Mr. Al-Khasawnhe, id., at 147, para. 18; Mr. Sreenivasa Rao, id., at 151, para. 46; Mr. Al-Qaysi, id., at 158, para. 32. 
Rodriguez, Mr. Beesley and Mr. Bennouna, opposed the different approach to pollution harm and to other kinds of harm, and who defended the thesis that the ILC should not allow a raising of the prohibited level for any kind of harm. ${ }^{105}$ As to the classification of the obligation not to cause appreciable pollution harm to other watercourse States as an obligation of due diligence, opinions varied. ${ }^{106}$ Draft Article 16 concerning pollution, though provoking various arguments among the ILC members, was finally submitted to the Drafting Committee without modification. ${ }^{107}$

At the stage of the Drafting Committee and the Provisional Draft, the dichotomy of pollution harm and harm from other causes advocated by McCaffrey was not adopted; instead Evensen's position was followed, not allowing a raising of the level of harm from whatever source to be prevented, namely appreciable harm, by the equitable utilization principle, unless a watercourse agreement provides otherwise. The ILC thus adopted the position that utilization of an international watercourse was not equitable - prima facie,

105 See the Statement of Mr. Calero Rodrigues, id., at 127, para. 5; Mr. Beesley, id., at 128, para. 15; Mr. Bennouna, id., at 134, para. 6.

${ }_{106}$ For supporters, see the Statement of Mr. Barboza, $i d$., at 124, paras. 27-28, at 136, paras. 19-20; Mr. Ogiso, id., at 135, para. 15; Mr. Mahiou, id., at 139, para. 5; Mr. Arangio-Ruiz, id., at 141, para. 21; Mr. Beesley, id., at 156, para. 15. For objectors, see the Statement of Mr. Calero Rodrigues, $i d$., at 127, paras. 4-5; Mr. Bennouna, $i d$., at 134, paras. 5, 7; Mr. Koroma, id., at 153, para. 72; Mr. Thiam, $i d$., at 159, para. 7, at 165, para. 69. For those showing some hesitation, see the Statement of Mr. Barsegov, id., at 145, para. 46; Mr. Shi, id., at 140, para. 13; Mr. Tomuschat, id., at 146, para. 8; Mr. Roucounas, $i d$., at 152 , para. 61 . Those who expressed objection or hesitation were concerned about the increase of pollution as a result of the introduction of such an ambiguous concept as due diligence. However, Mr. Barsegov was afraid that the stipulation of too peremptory a prohibition could have an adverse impact on economic activity notwithstanding the introduction of the concept of due diligence. See the Statement of Mr. Barsegov, id., at 145, para. 46. While opinions of governments also varied, there were at least the following twelve States that clearly supported the concept of due diligence. [International Watercourse States] (b) Middle Riparian States: Canada, Hungary, Federal Republic of Germany, Austria, Ethiopia, the United States, the Netherlands. See for Canada, UN Doc., A/C.6/43/SR.29, at 4. para. 11; Hungary, SR.30, at 11, para. 37; Federal Republic of Germany, SR.31, at 3, para. 6; Austria, $i d$., at 22, para. 102; Ethiopia, SR.32, at 4, paras. 15-17; the United States, A/CN.4/447, at 42; the Netherlands, A/CN.4/447/Add.3, at 5-6. (c) Lower Riparian States: Jordan. See SR.39, at 9, para. 39. [Non International Watercourse States] Japan, Jamaica, Bahrain, Bahamas. See for Japan, SR.31, at 5, para. 15; Jamaica, SR.35, at 13, para. 58; Bahrain, SR.37, at 11, para. 52; Bahamas, SR.39, at 23, para. 108. Those States which either supported strict liability or criticized the concept of due diligence were, to this author's knowledge, limited to five middle riparian States, namely, Venezuela, USSR, Greece, Ukranian SSR and Pakistan. See for Venezuela, SR.29, at 7, para. 29; USSR, SR.30, at 15, para. 56; Greece, SR.31, at 14, para. 58; Ukranian SSR, $i d$., at 15, para. 66; Pakistan, SR.35, at 3-4, para. 9. Morocco, a middle riparian State, thought that it depended on circumstances in which the standard of due diligence obligation or strict liability, would apply. See SR. 31, at 19-20, para. 89.

107 YILC, 1988, Vol. I, at 168, para. 4; 1989 ILC Report, YILC, 1989, Vol. II, Part Two, at 123, para. 630 . 
at least - as soon as it causes other watercourse States appreciable harm. ${ }^{108}$ This is shown in the following articles: Article 8 of the Drafting Committee's Draft $^{109}$ and Article 7 of the Provisional Draft, providing for the obligation to prevent appreciable harm; Article 23, paragraph 2, of the Drafting Committee's Draft ${ }^{110}$ and Article 21, paragraph 2, of the Provisional Draft as to pollution prevention. On the other hand, it was not clarified at that stage whether the obligation to prevent appreciable (pollution) harm to other States was one to be based on due diligence, which would have a relaxing impact. ${ }^{111}$

Having thus reviewed the ILC discussions, the observations submitted by the various governments will now be examined. There were three kinds of positions: the first position supported the reasoning embodied in the Provisional Draft. It was the position taken by the Republic of Korea, a lower riparian State, as well as the United Kingdom and Germany, both middle riparian States. These latter two States suggested that the adjective "apprecia-

108 See 1988 ILC Report, op. cit. n. 15, at 36, paras. (2)-(3); YILC, 1988, Vol. I, at 180, para. 35. This position was unclear as to Article 23, paragraph 2, of the Drafting Committee's Draft and Article 21 paragraph 2 of the Provisional Draft concerning the obligation to prevent pollution. However, it should be noted that this obligation was said to be a specific application of the general obligation contained in Article 7 of the Provisional Draft not to cause appreciable harm to other watercourse States. 1990 ILC Report, op. cit. n. 49, at 161, para. (3). Moreover, it should also be noted that, during the debate on Article 16, paragraph 2, of McCaffrey's Draft, there was no objection among other members against taking such a strict position at least in the case of pollution.

109 YILC, 1988, Vol. I, at 180, para. 34.

110 YILC, 1990, Vol. I, at 282, para. 26.

111 The Drafting Committee itself seems to have understood that its draft Article 8 was a provision concerning responsibility for wrongful acts, not one concerning so-called "liability for lawful acts". It is because, in para. (8) of the commentary attached to this article, there initially existed the first sentence saying that "[a] breach of Article 8 would engage the international responsibility of the watercourse State in question". See the Statement of Mr. Calero Rodrigues, YILC, 1988, Vol. I, at 333, para. 61. However, certain members reserved their positions with regard to Article 8 and the commentary thereon by reason of the unclearness of the nature of the international responsibility in question. See 1988 ILC Report, op. cit. n. 15, at 35, footnote 111. See also the Statement of Mr. Graefrath, YILC, 1988, Vol. I, at 332, paras. 56-58; Mr. Barsegov, id., at 332, para. 59. Moreover, a member objected to that sentence since the ILC had not yet considered the nature of international responsibility in question in sufficient depth. See the Statement of Mr. Calero Rodriguez, id., at 333, para. 61. As a consequence, para. (8) of the commentary was deleted. Id., at 333, para. 64. McCaffrey regarded Article 7 of the Provisional Draft adopted against this background as stipulating an obligation, which would lead to responsibility for wrongful acts but was an "obligation of result" that does not need the requirement of due diligence. See McCaffrey, op. cit. n. 74, at 519-525. There was no discussion about the nature of the obligation during the deliberations on Article 23, paragraph 2, and the commentary of the Drafting Committee's Draft concerning the obligation to prevent pollution. See YILC, 1990, Vol. I, at 282-285, paras. 26-63, at 364-365, paras 6-32; YILC, 1991, Vol. I, at 164, para. 59. Nevertheless, the adopted commentary, saying that due diligence shall be exercised in reducing the pollution, suggests that the obligation is one of due diligence. See 1990 ILC Report, op. cit. n. 49, at 162, para. (4). 
ble" should be replaced by the adjective "significant". ${ }^{112}$ The second position argued that the ILC should avoid the level of harm to be prevented, viz. appreciable harm, from being raised by the equitable utilization principle in case of pollution, while allowing such a rise in case of harm by other causes. The Nordic countries, Switzerland, Canada and the Netherlands, all middle riparian States, took this position. In addition, Switzerland suggested that the adjective "appreciable" be replaced by another one, like "significant", "major", "substantial" or "serious", which reflected more faithfully the status quo in customary law. ${ }^{113}$ Finally, under the third position a raising was allowed in principle except in some cases, though not specified as those of pollution, where such a rise cannot be allowed. The United States, a middle riparian State, as well as Australia, a non-riparian State, were supporters of this view. Nevertheless, both States seem to have had in mind especially the case of pollution as a typical one where such a rise cannot be allowed. Besides, the United States was concerned that the adjective "appreciable" would set too low a threshold, and suggested that the adjective in question should be replaced by such adjectives as "significant", "substantial" or "serious". 114

In view of the foregoing, at least the following two points can be made concerning pollution harm: first, if the level of harm to be prevented is set at a higher level, viz. serious harm, States seem to have generally accepted that such a level should not be raised any further by the equitable utilization principle subject to contrary treaty law; secondly, in so far as the adjective "appreciable" is understood to have the same meaning as "significant", many States seem to have accepted the strict position of the Provisional Draft as it sets the level in question at a lower level, viz. appreciable harm, and does not admit a raising by the equitable utilization principle of even that lower level, although this is as always subject to contrary treaty law. By way of argument supporting this second observation, it may be noted that draft Article 7 of Rosenstock's first report of 1993 provides that "a use which causes significant harm in the form of pollution shall be presumed to be an inequitable and unreasonable use" barring certain circumstances. ${ }^{115}$ It is true that Article 7 of the 1994 Final Draft merely provides that the State of origin shall

\footnotetext{
112 See for the Republic of Korea, UN Doc.,A/C.6/43/SR.31, at 24, para, 109; Germany, A/CN.4/447, at 20; the United Kingdom, id., at 35.

113 See for Nordic Countries, id., at 27; Switzerland, id., at 47-48, 51, 53; Canada, UN Doc., A/CN.4/ 447/Add.1, at 4-5; the Netherlands, A/CN.4/447/ Add.3, at 9.

114 See for the United States, UN Doc., A/CN.4/447, at 39-41; Australia, A/C.6/43/ SR. 30, at 4, para. 10. Poland, too, claimed to delete the "appreciable harm" threshold. However, it is because Poland, a lower riparian State, was afraid that the adoption of that threshold which lacks objective criteria might cause the increase of pollution, not because it regarded that threshold as too low. See A/CN.4/447/Add.1, at 10.

115 Rosenstock, First Report, op. cit. n. 15, at 10-11, para. 25. The said circumstances are as follows: (a) a clear showing of special circumstances indicating a compelling need for ad hoc adjustment; and (b) the absence of any imminent threat to human health and safety. Loc. cit.
} 
consult with the affected State over a higher level of harm to be prevented as a result of the equitable utilization principle, without making a distinction between pollution harm and other kinds of harm. ${ }^{116}$ The purport of Rosenstock's Draft is specified in the commentary thereon. ${ }^{117}$ However, it may be that the "second point" referred to above has not been accepted by those States, such as Switzerland and the United States, which insist on setting a higher level, viz. serious harm. However, it should also be borne in mind that the observations of the governments were submitted at the time when it was still unclear whether the obligation not to cause appreciable (pollution) harm would be one of due diligence, which would relax the strict position of the Provisional Draft. If this were the case, the number of States in support of a strict position would certainly become higher. ${ }^{118}$

Thus, the 1994 ILC Final Draft was elaborated, on the basis of which the 1997 Watercourses Convention ${ }^{119}$ was drafted. As the positions of the Final Draft and the Convention are very similar, we shall focus on the Convention, mentioning the Final Draft for reference only.

\footnotetext{
116 See 1994 ILC Report, op. cit. n. 3, at 236. Professor Bourne regards the 1994 Final Draft as sustaining "the priority of the principle of equitable utilization over no significant harm rule". It is because "the Article [Article 7] does not prohibit a use that is equitable and reasonable and done with due diligence, even though the use causes significant harm to other watercourse States." Charles B. Bourne, "The primacy of the principle of equitable utilization in the 1997 watercourses convention", 35 CYIL (1997) 215 at 224.

117 See 1994 ILC Report, op. cit. n. 3, at 241-242. McCaffrey thinks that "[t]he final version of the draft [the 1994 Final Draft] does not completely reverse the primacy of the no-harm rule but softens the regime considerably". The reason is that "[t]he change from prohibition [of significant harm as stipulated in the Provisional Draft] to process [aimed at avoiding significant harm as far as possible while reaching an equitable result in each concrete case as stipulated in the Final Draft] is a major one indeed." McCaffrey, "An assessment of the work of the International Law Commission”, 36 NRJ (1996) 297 at 309. Likewise, Dr. Wouters regards the Final Draft as maintaining "the no significant harm rule as the governing rule of watercourse law", though in her view this position is not in conformity with State practice recognizing the primacy of the equitable utilization principle. Patricia K. Wouters, "An assessment of recent developments in international watercourse law through the prism of the substantive rules governing use allocation", 36 NRJ (1996) 417 at 424, 436-439. Interestingly, Professor Utton proposed that there should be a distinction in the Final Draft between water quantity matters where the equitable utilization principle should prevail and water quality matters where the "no significant harm" rule should prevail. Albert E. Utton, "Which rule should prevail in international water disputes: that of reasonableness or that of no harm?", 36 NRJ (1996) 635 at 639-641.

118 In Article 7 of the Final Draft, the term "due diligence" is specified. See id., at 236. Article 7 of the 1997 Watercourses Convention, too, contains the concept of due diligence, as will be seen in the next Part.

119 See 36 ILM (1997) 700.
} 


\title{
5. THE POSITION OF THE 1997 WATERCOURSES CONVENTION
}

The relationship between the No pollution harm and the Equitable utilization principles was a contentious issue until the last minute of the discussions in the working group of the Sixth Committee of the United Nations General Assembly. The final solution was reached on 4 April 1997, the last day of the session, by treating Articles 5, 6 and 7 as one package, as proposed by the Chairman Chusei Yamada. ${ }^{120}$ In the end, the relationship was dealt with in Article 7, which reads as follows:

\begin{abstract}
1. Watercourse States shall, in utilizing an international watercourse in their territories, take all appropriate measures to prevent the causing of significant harm to other watercourse States.

2. Where significant harm nevertheless is caused to another watercourse State, the States whose use causes such harm shall, in the absence of agreement to such use, take all appropriate measures, having due regard for the provisions of articles 5 and 6 , in consultation with the affected State, to eliminate or mitigate such harm and, where appropriate, to discuss the question of compensation. ${ }^{121}$ (emphasis added)
\end{abstract}

Article 7 thus contains prescriptions on, on the one hand, ex ante prevention of harm in paragraph 1 , and, on the other hand, ex post remedial measures ${ }^{122}$ (elimination or mitigation of harm and discussion on the question of compensation) in paragraph 2. This two-faceted regulation followed the formulation of the Final Draft. ${ }^{123}$

The text of the article shows that no distinction is made between harm from pollution and harm by other causes. This position conformed to that taken by the Final Draft. Against this background one would suspect the existence of some influence of the following considerations: Article 7 deals with transfrontier harm in general, separate from Article 21 concerning prevention of harm caused by pollution; ${ }^{124}$ and different treatment between

\footnotetext{
${ }^{120}$ UN Doc., A/C.6/51/NUW/WG/CRP.94; A/C.6/51/SR.61,62,62/Add.1.

12136 ILM (1997) 706.

122 According to the 1992 decision by the ILC on the topic of the International Liability, those measures designed for mitigation or elimination of harm are classified not as prevention but as remedial measures. See UN Doc., A/47/10, at 128.

${ }_{123}$ See 1994 ILC Report, op. cit. n. 3, at 236.

124 See the following statement of Mr. Bennouna: "What was most important was the relationship between Articles 5 and 7, which lay at the very heart of the topic. The new wording proposed for Article 7 was not clear, however, and also had the drawback of introducing the problem of pollution, which was already covered by Article 21, without establishing any connection with that article. In reducing harm to cases of pollution, the Special Rapporteur was really gong too far." YILC, 1993, Vol. I, at 99, para. 25.
} 
pollution harm and harm other than pollution would be cumbersome for the statement of a general principle. ${ }^{125}$

By way of a second comment on Article 7 attention should be drawn to the fact that both paragraphs 1 and 2 contain the obligation to take "all appropriate measures". This expression was adopted instead of "exercise due diligence" as appeared in Article 7 of the Final Draft, without intention of modifying its substance. This means that the said obligation is meant to be a "due diligence" obligation. ${ }^{126}$ According to the explanation of Chairman Yamada, the change in formulation was intended to stress the obligation of the State of origin while limiting the scope of that obligation without abandoning the element of "due diligence". ${ }^{127}$

\subsection{Ex ante prevention of harm (Article 7, paragraph 1): rejection of "relaxation"}

There is no reference to the equitable utilization principle in paragraph 1 , and consequently there is no room for the "relaxation" of the obligation of ex ante prevention of harm. The State of origin is thus not allowed to justify $a b$ initio the occurrence of harm beyond the "significant" level by arguing its "equitable use" of the watercourse.

\footnotetext{
${ }^{125}$ Mr. Yankov stated as follows: "Commenting on article 7, relating to the obligation not to cause appreciable (or significant) harm, ...the revised text proposed by the Special Rapporteur was unnecessarily cumbersome for the statement of a general principle. (...) ...the presumption relating to pollution and the modalities and limits of that presumption, would not contribute to the general improvement of that article." YILC, 1993, Vol. I, at 100, para. 40. Similar statements were made by Mr. Razafindralambo. YILC, 1994, Vol. I, at 48, para. 30.

126 The obligation to prevent environmental harm (Articles 21, 22 and 23) is clearly stated as a "due diligence" obligation. See 36 ILM (1997) 720.

127 A letter dated 6 April 1998 from Mr. Yamada. According to him, this alteration of expression was a compromise with the request for the deletion of "due diligence" made by such environmentalist States as European States and the United States, as well as by some of the downstream States. There was also a criticism that the expression of "due diligence" confused questions of liability with the preventive duties. See the Comments by Finland, UN Doc., A/51/275, at 42. As regards the expression "take all appropriate measures", it was adopted in Article 2, paragraph 1, of the 1992 Convention on the Protection and Use of Transboundary Watercourses and Lakes [hereinafter, the Transboundary Watercourses Convention] (17 March 1992, Helsinki), 31 ILM (1992) 1312. This Convention is mentioned by the commentary on Article 7 of the 1994 Final Draft as an example applying the "due diligence" standard. See A/49/10, at 239.
} 


\subsection{Ex post remedial measures [elimination or mitigation of harm and discussion on the question of compensation] (Article 7, para- graph 2)}

Contrary to paragraph 1 , paragraph 2 does refer to the equitable utilization principle stipulated in Articles 5 and 6. However, it should be noted that paragraph 2 covers the case where significant harm occurs notwithstanding the effort to prevent it with "due diligence". If such harm occurs as a result of a lack of "due diligence", however, there would be an occurrence of a breach as foreseen in paragraph 1, with the consequent obligation to stop and undo the (unlawful) act immediately; that is, by eliminating the harm and by making reparation, without considering an eventual "equitable use".

\subsubsection{The situation where "relaxation" can be argued: reduction of con- tinuous pollution (ex post prevention of harm)}

It should be examined whether the "relaxation" of the no pollution harm principle can be argued in the phase of ex post remedial measures, as covered by paragraph 2 .

Although harm prevention and ex post remedial measures might look contradictory, when continuous harm occurs, its elimination or mitigation by way of ex post remedial measures may be achieved by preventing additional harm. ${ }^{128}$ Since the no pollution harm principle operates in this situation, the "relaxation" of this principle could be considered.

On the other hand, when the elimination or mitigation of harm refers to pollution which has already reached other States, or when compensation is paid for harm which has already occurred in other States, the no pollution harm principle does not operate; the measures required here concern the restoration of the original situation, and not ex post prevention of harm. Therefore, there is no place for any "relaxation" of the no pollution harm principle. ${ }^{129}$

\subsubsection{A negative attitude toward "relaxation"}

Article 7, paragraph 2, shows the negative attitude toward "relaxation", especially in the case of pollution harm. First, the expression "having due regard to" the equitable utilization principle in paragraph 2 is the result of

\footnotetext{
128 This played a role in the Trail Smelter case.

129 There are some arguments on the nature of the obligation to eliminate or mitigate the harm that has already occurred notwithstanding the effort to prevent it with "due diligence", as well as on the nature of the obligation to compensate for the harm thus caused. Barboza thinks these obligations as reflecting the concept of "liability for lawful acts". See YILC, 1994, Vol. I, at 177, para. 55 .
} 
the rejection of other expressions such as "consistent with" 130 or "without prejudice to", ${ }^{131}$ as proposed by those States which strongly asserted the element of "relaxation". 132

Secondly, it is to be noted that the commentary on Article 7 of the Final Draft states that " $[\mathrm{t}]$ he burden of proof for establishing that a particular use is equitable and reasonable lies with the State whose use of the watercourse is causing significant harm". ${ }^{133}$

Thirdly, the same commentary points out that a use that causes "significant harm to human health and safety" or "any other form of extreme harm" should be regarded as "inequitable and unreasonable". ${ }^{134}$ This appears to imply a rejection of the "relaxation" of the obligation to prevent irreparable or serious harm, especially in the case of pollution, even in the phase of ex post prevention of harm.

\subsection{Summing-up}

From the above inquiry we can summarize the position of the 1997 Watercourses Convention towards transfrontier pollution harm as follows: first, in the phase of ex ante prevention of harm, it does not allow the level of harm to be prevented (=significant harm) to be raised by the equitable utilization principle; secondly, in the phase of ex post prevention of harm, it allows such a rise, but puts the burden of proof for establishing the equitableness and reasonableness of the use on the State of origin; and, finally, even in the phase of ex post prevention of harm, the Convention does not allow a rise to such an extent that irreparable or serious harm would occur.

Meanwhile, as Professor Bourne insists, "it would seem to be impossible to argue successfully that the provisions of this Convention are accepted as customary law by international community". ${ }^{135}$ Yet we would suggest that

\footnotetext{
${ }^{130}$ See Revised Text of Article 7 Proposed by Austria, Canada, Portugal, Switzerland and Venezuela, UN Doc., A/C.6/51/NUW/WG/CRP.72.

131 For example, Rumania, UN Doc., A/C.6/51/NUW/WG/CRP.23; Turkey, /CRP.24; Ethiopia/ CRP.51.

132 Those States which strongly asserted the "relaxation" expressed their regret in this respect at the United Nations General Assembly where the 1997 Watercourses Convention was adopted. See op. cit. n. 82. However, the expression "having due regard to" was adopted in place of the expression "taking into account", which means that some considerations were given to those States. See UN Doc., A/C.6/51/NUW/WG/CRP.94.

1331994 ILC Report, op. cit. n. 3, at 241-242, para. 14. The Commentary to the 1994 Final Draft was also referred to when the 1997 Watercourses Convention was drafted. See UN Doc., A/51/869, at 6 .

1341994 ILC Report, op. cit. n. 3, at 242, para. 14.

135 Bourne, op. cit. n. 116, at 231. In the Working Group of the sixth Committee of the United Nations General Assembly, Articles 5, 6 and 7 as a package were adopted by 38 votes to 4, with 22 abstentions, and the Convention as a whole was adopted by 42 votes to 3, with 19 abstentions.
} 
the majority of the international community does not want the no pollution harm principle to be relaxed too easily through application of the equitable utilization principle. ${ }^{136}$

\section{AN EXAMINATION OF SOME JUDICIAL PRECEDENTS AND STATE PRACTICE}

The position against the "relaxation" of the no pollution harm principle by the equitable utilization principle is compatible with judicial precedents and State practice. However, though the obligation to prevent at least a serious level of pollution harm is well established under customary international law, it is still uncertain whether that is equally the case with the obligation to prevent an appreciable (=significant), viz. less than serious, level of pollution harm. ${ }^{137}$ Therefore, in analysing current customary international law, we shall limit our examination to the question whether the level of pollution harm to be prevented may be raised further from the serious level by the equitable utilization principle. With regard to the issue of the appreciable (=significant) level of harm, we shall confine ourselves to indicating recent tendencies of State practice.

As to international courts and tribunals, ${ }^{138}$ reference should be made to the Trail Smelter case, where the decision was made based on the analogy between water pollution and air pollution, and where the consideration of

UN Doc., A/C.6/51/ SR.62, at 3, para.8; SR.62/Add.1, at 2, para. 3. In the 99th plenary meeting of the United Nations General Assembly, the Convention was adopted by 103 votes to 3, with 27 abstentions. A/51/PV.99, at 8 .

${ }^{136}$ Bourne is ready to accept the proposition that an act which causes significant harm is presumed to be necessarily unreasonable and inequitable if this presumption is rebuttable. Bourne, op. cit. n. 116, at 227. Therefore, there might be little contradiction between his and our positions; we have no intention to allege that this presumption is irrebuttable. We allege, however, that irreparable or serious harm caused by pollution should be regarded (not presumed) as inequitable and unreasonable, therefore, without allowing for any rebuttal.

137 An author points out that the level of pollution harm to be prevented under customary international law recently becomes lowered from the serious level to the significant level. K. Sachariew, "The definition of thresholds of tolerance for transboundary environmental injury under international law: development and present status", 37 NILR (1990) 193 at 205-206. Moreover, in the Sixth Committee of the United Nations General Assembly in 1988, some representatives of the governments explicitly objected to replacing the adjective appreciable by that of substantial or serious during the deliberations on draft Article 16, paragraph 2, of McCafrrey's fourth report prescribing the obligation to prevent pollution. See the Statement of the Representative of Qatar, UN Doc., A/C.6/43/SR.30, at 2, para. 3; Australia, id., at 4, para. 10. But, to the contrary, other representatives supported such a replacement. See the Statement of the Representative of France, SR.26, at 5-6, para. 19; German Democratic Republic, SR.31, at 4, para. 10; Bahrain, SR.37, at 11, para. 52; Thailand, SR.39, at 5, para. 18 .

138 As regards this question, it seems that no suggestion can be obtained from the Lake Lanoux arbitral award of 1957. Professor Handl regards the award as admitting the application of the 
"equitable use" was included in the obligation to prevent, with due diligence, serious transfrontier pollution harm. ${ }^{139}$ Consequently, the Tribunal did not accept the "relaxation" of the obligation not to cause serious pollution harm. ${ }^{140}$

Turning to decisions of domestic courts with reference to the rules of international law concerning pollution of international watercourses, the District Court of Rotterdam in its final decision on the Mines de Potasse d'Alsace case of 1983 held that there did not exist "any rule of international law" which justified the derogation from the State obligation not to cause substantial injury. ${ }^{141}$ Therefore, this decision, too, can be regarded as denying the "relaxation" of the obligation not to cause serious pollution harm. ${ }^{142}$

Thirdly, we shall examine decisions on pollution matters of the Supreme Court of the United States, which dealt with the quasi-sovereign rights of the States of the Union and which were also invoked in the Trail Smelter arbitral award. ${ }^{143}$

In State of Missouri v. State of Illinois, of 1906, concerning sewage pollution of the Illinois river, the Court stated, "Before this court ought to

balancing of interests concerning pollution. It is because in his view the tribunal and the government of Spain understood that Article 12 of the Additional Act to the Treaty of Bayonne, on the basis of which the tribunal seemed to have judged the case, was subject to the principle of good neighbourliness. Handl, op. cit. n. 5, at 180. It is true that in some authors' views the essence of the principle of good neighbourliness lies in the balancing of interests. Others, however, think that it lies in the mere tolerance of a certain degree of harm. See Lammers, op. cit. n. 2, at 568-569. Therefore, it seems rather unreasonable to understand the award as Handl does, paying sole attention to the application of the principle of good neighbourliness. Moreover, it should also be noted that the argument of Spain referring to the principle of good neighbourliness was not limited to pollution but related to water utilization in general. See 12 RIAA, at 304.

139 See Bourne, "International law and pollution of international rivers and lakes", 6 Univ. of British Columbia Law Review (1971) 115 at 131.

140 This can also be understood by the fact that the arbitral tribunal ordered in its award the implementation of a rather strict prevention régime which would, in its opinion, "probably result in preventing any damage of a material nature". See 3 RIAA, at 1980.

14115 NYIL (1984) at 481.

142 This judgment often referred to "balancing of interests" in applying Dutch delictual law which is seen, in the view of the court, as compatible with international law. But this "balancing of interests" was used as a criterion to decide whether or not due diligence under Dutch delictual law was absent, not as a doctrine to raise the level of harm to be prevented. See id., at 474-479.

143 The Arbitral Tribunal held as follows: "...the law followed in the United States in dealing with the quasi-sovereign rights of the States of the Union, in the matter of air pollution, whilst more definite, is in conformity with the general rules of international law." 3 RIAA, at 1963. "...it is reasonable to follow by analogy, in international cases, precedents established by that court [the Supreme Court of the United States] in dealing with controversies between States of the Union or with other controversies concerning the quasi-sovereign rights of such States, where no contrary rule prevails in international law and no reason for rejecting such precedents can be adduced from the limitations of sovereignty inherent in the Constitution of the United States [emphasis added]." Id., at 1964. 
intervene, the case should be of serious magnitude, clearly and fully proved", and dismissed without prejudice the claim for an injunction by the complainant because of insufficient proof of the causal relationship between the sewage pollution and the harm. ${ }^{144}$ In People of the State of New York $v$. State of New Jersey, of 1921, concerning sewage pollution of New York bay, the complainant's claim for an injunction was also dismissed without prejudice, for the same reason. ${ }^{145}$ In neither of these decisions was the dismissal of the claim based on the allowance of the "relaxation" of the obligation not to cause serious pollution harm.

In New Jersey v. City of New York, of 1931, the claim for an injunction against dumping of noxious materials into the ocean was allowed. In this judgment a "reasonable time" was accorded to the City of New York before the injunction should be issued. This indicates the consideration of "equitable use". However, because the dumping itself was prohibited completely, ${ }^{146}$ the decision cannot be regarded either as allowing the "relaxation" of the obligation not to cause serious pollution harm.

The next case that comes to mind is State of Georgia v. Tennessee Copper Company, of 1907 and 1915, concerning air pollution by sulphur dioxide. ${ }^{147}$ In its decision of 1907, the Court did not exclude "the considerations that equity always takes into account". ${ }^{148}$ Nevertheless, the Court rejected the defendant's argument, holding, "we cannot give the weight that was given them [the considerations that equity always takes into account] in argument to a comparison between the damage threatened to the plaintiff and the calamity of a possible stop to the defendant's business, the question of health, the character of the forests as a first or second growth, the commercial possibility or impossibility of reducing the fumes to sulphuric acid, the special adaptation of the business to the place". ${ }^{149}$ Consequently, the Court held, "[i]t is a fair and reasonable demand on the part of a sovereign that the air over its territory should not be polluted on a great scale by sulphurous acid gas... . ."150 In its decision of 1915, the Court issued a decree to reduce partially the amount of discharge of the sulphur contained in the fumes, ${ }^{151}$ which was to "diminish materially the present probability of damage to its [the State of Georgia's] citizens". ${ }^{152}$ As a result these two decisions can

144 State of Missouri v. State of Illinois and the Sanitary District of Chicago, 200 US (1906) 496 at 521-526.

145 People of the State of New York v. State of New Jersey and Passaic Valley Sewerage Commissioners, 256 US (1921) 296 at 312-314.

146 State of New Jersey v. City of New York, 283 US (1931) 473 at 483.

147 State of Georgia v. Tennessee Copper Company and Ducktown Sulphur, Copper, \& Iron Company, 206 US (1907) 230, 237 US (1915) 474.

148206 US 238.

149 Loc. cit.

150 Loc. cit

151237 US 478.

152 Id., at 477. 
be regarded as denying the "relaxation" of the obligation not to cause serious pollution harm.

Lastly, we have examined New Jersey $v$. New York, of 1931, concerning the diversion of water from the Delaware River, which also dealt with the quasi-sovereign rights of the States of the Union, but which was not invoked in the Trail Smelter arbitral award. ${ }^{153}$ In this case, the plaintiff had argued, as one of the reasons for demanding an injunction against the diversion intended by the defendant, the possibility that injury to the oyster industry would occur because of chloride pollution derived from that diversion. ${ }^{154}$ Although the Court did emphasize the principles of "equitable apportionment" and "equitable division", ${ }^{155}$ such emphasis on the equitable utilization principle can be regarded as quite natural because the main issue of the case rested on the problem of diversion. ${ }^{156}$ Moreover, although the Court did not admit a full-scale injunction, it prohibited the diversion of water in excess of 440 million gallons daily, ${ }^{157}$ after having confirmed that "the taking of 600 millions of gallons daily will [would] not materially affect the River or its sanitary condition..."158 Therefore, this decision, too, cannot be regarded as allowing the "relaxation" of the obligation not to cause serious pollution harm. ${ }^{159}$

Most of the US judicial precedents examined here dealt with conflicts between a State (or company) that had newly started industrial activities involving pollution and a State (or people) trying to protect its (their) acquired interests, viz. a clean environment. Despite these specific contexts, the analysis leads us to the following conclusion: under customary international law, a higher minimum level of the harm to be prevented, viz. serious harm, is not to be raised further by the equitable utilization principle unless so prescribed by agreement. This conclusion holds true of ex ante as well as ex post prevention of harm, as is shown by the Trail Smelter and the State of Georgia v. Tennessee Copper Company cases. Moreover, the conclusion seems to be supported by the analysis of treaties ${ }^{160}$ and other State practice. ${ }^{161}$ For

\footnotetext{
153 New Jersey v. New York et al., 283 US (1931) 336.

154 Id., at 343 .

155 Id., at 343-344.

156 This may explain the non-invocation of the decision by the Trail Smelter arbitral award.

157 Id., at 346.

158 Id., at 345 .

159 Contra Bourne, op. cit. n. 139, at 131.

160 Although there are many treaties providing for the equitable utilization principle, few among them include provisions on pollution. See McCaffrey, Second Report, op. cit. n. 16, at 134-138. There are also many treaties providing for the obligation to prevent pollution of international watercourses, but most of them merely stipulate that a certain kind or degree of pollution harm shall be prevented, or co-operation to this end shall be made. See Lammers, op . cit. n. 2, at 115-123; Nollkaemper, op. cit. n. 12, at 68. This fact could be invoked for the argument that the "relaxation" of the obligation not to cause serious pollution harm cannot be allowed. Several treaties referring to the equitable utilization principle in the context of the obligation to prevent pollution do not make
} 
example, in the Poplar River Project incident ${ }^{162}$ the United States, taking account of the equitable utilization principle, had tolerated the occurrence of some aggravation of the water quality caused by the pollution originated from a Canadian coal-fired power plant. ${ }^{163}$ Canada expressed its intention to adopt measures to reduce pollution, in accordance with international law, whereupon the United States expressed its satisfaction. ${ }^{164}$

The agreement between Finland and Sweden concerning frontier rivers of $1971^{165}$ allows "balancing of interests" in respect of pollution (Chapter 6, Article 6) and even allows those operations likely to cause "substantial inconvenience" "if special reasons exist for so doing" (the first half of Chapter

their positions clear in this respect. For example, see Article 4, paragraph 10, of the Indus Waters Treaty Concluded between India and Pakistan (19 September 1960, Karachi), Legislative texts and treaty provisions concerning the utilization of international rivers for other purposes than navigation [hereinafter, Legislative Texts], UN Doc., ST/LEG/ SER.B/12, at 300, No. 98.

161 An example can be shown by the Sandoz blaze of 1986 where the Rhine river was polluted by the flow of chemicals run from a factory in Switzerland. However, in this accident, the claims for indemnity were disposed of at the private level, and State responsibility of Switzerland was not called into question. Hans Ulrich Jessurun D'Oliveira, "The Sandoz blaze: the damage and the public and private liabilities", in Francesco Francioni \& Tullio Scovazzi (eds.), International responsibility for environmental harm (London: Graham \& Trotman, 1991) 429 at 439. As regards State practice before 1983, see Lammers, op. cit. n. 2, at 165-341.

162 In this incident, the matter was referred to the International Joint Commission (IJC) between the United States and Canada established by the Boundary Waters Treaty of 1909, on the ground that the construction of a thermal power station by Canada in the Poplar river basin might cause pollution harm to the United States. See Eleanor C. McDowell, 1976 Digest of United States practice in international law [hereinafter, 1976 Digest], (Washington D.C.: U.S. Government Printing Office, 1977), at 590-594. See also Marian Lloyd Nash, 1978 Digest (1980) at 1116-1121; 1979 Digest (1983) at 1103-1111, 1612-1616. Although the IJC has the power to render a decision by a majority, reports of the IJC shall not be regarded as decisions, and shall in no way have the character of an arbitral award. See Articles 8, 9 and 10 of the Treaty between Great Britain and the United States Relating to Boundary Waters, and Questions Arising between the United States and Canada (11 January 1909, Washington), Legislative Texts, op. cit. n. 160, at 260, No. 79.

163 In 1981 the IJC, taking account of the equitable utilization principle, decided that, while the use of waters would cause some adverse water quality impacts on uses of the United States, this fact alone would not constitute an automatic violation of Article 4 of the Boundary Waters Treaty of 1909. Moreover, the IJC stated as follows: "issues of equitable apportionment and the obligations of Article 4 must be examined at the same time"; "water quality objectives can equally well be viewed as one of the conditions of an equitable apportionment". See Wouters, "Allocation of the non-navigational uses of international watercourses: efforts at codification and the experience of Canada and the United States", 30 CYIL (1992) 43 at 75. Both Parties accepted the conclusion of the report of the IJC. In this incident air pollution was at the same time emanated from Canada's power station in question. This would cause the reduction of permissive pollution emission quantity allocated to power stations in the United States, and therefore might cause a certain degree of economic damage. See Quentin- Baxter, Fourth Report on Liability, YILC, 1983, Vol. II, Part One, at 211 , para. 36 .

164 McCaffrey, Fourth Report, op. cit. n. 2, at 236, para. 87.

165 (16 September 1971, Stockholm), 825 UNTS (1972) at 191. However, it should be noted that this agreement prescribed rights and obligations between private persons, not between States. 
6, Article 7) on the condition of payment of compensation (Chapter 7, Article 1). At the same time, however, the agreement provides that "the operations may not be carried out" "[w]hen the anticipated inconvenience entails a substantial deterioration in living conditions for a large number of people or a significant loss from the standpoint of nature conservancy or any similar substantial damage to the public interest" (the latter half of Chapter 6, Article 7). ${ }^{166}$

As to appreciable (=significant) harm, there are many treaties stipulating the obligation to prevent such a level of harm through pollution, ${ }^{167}$ as well as some State practice recognizing the obligation to prevent pollution harm even less than the appreciable level. ${ }^{168}$ Like the Poplar River Project incident mentioned above, however, there is also some State practice tolerating the occurrence of pollution harm to some extent by taking account of the equitable utilization principle even in the phase of ex ante prevention of harm. On the other hand, recent tendencies in State practice seem gradually to accept a strict position as manifested by the obligation not to cause an appreciable (=significant) level of harm while not allowing any "relaxation" of that obligation, in both the ex ante and ex post phases of prevention of harm. This is shown by the 1992 Transboundary Watercourses Convention, ${ }^{169}$ which seems to recognize clearly that no deviation is allowed from the obligation "to prevent, control and reduce pollution of waters causing or likely to cause transboundary impact" (Article 2, paragraph 2(a)), even by invoking the equitable utilization principle (the same paragraph(c)). ${ }^{170}$

\section{THE 1997 DECISION OF THE INTERNATIONAL COURT OF JUSTICE IN THE GABČÍKOVO-NAGYMAROS PROJECT CASE ${ }^{171}$}

Although in this case there was no question of transfrontier pollution moving from Slovakia to Hungary, Hungary alleged that Slovakia's unilateral

\footnotetext{
166 The harm not allowable in the presence of a water agreement should still be less allowable in the absence of it.

167 See 1988 ILC Report, op. cit. n. 15, at 36-37, para. (7).

168 For example, in the Colorado River incident where the United States' drainage of saline waters into the Colorado River caused harm to Mexico, the maximum discharge quantity of salinity was said to be set down in the final agreement of 1973 between the two States so as to eliminate any adverse consequence of the drainage in question. See Herbert Brownell \& Samuel D. Eaton, "The Colorado River salinity problem with Mexico", 69 AJIL (1975) 255 at 270.

16931 ILM (1992) 1312.

${ }^{170} I d$., at 1315. Article 2, paragraph 7, of the Convention provides that "[t]he application of this Convention shall not lead to the deterioration of environmental conditions nor lead to increased transboundary impact". Id., at 1316.

${ }^{171}$ See op. cit. n. 25. On 3 September 1998, Slovakia asked the ICJ to render an additional Judgment because of the unwillingness of Hungary to implement the 1997 Judgment. See ICJ Press Communiqué 98/28 (3 September 1998). As of 31 March 2003, the ICJ has not done so yet.
} 
diversion of water of the Danube river ("Variant C") caused (the risk of) environmental harm within the territory of Hungary. ${ }^{172}$ As a result, the relationship between the equitable utilization principle and the no harm principle became involved. This case will be examined separately because of its importance for the study of international law.

On the one hand, Hungary argued for the priority of the no harm principle over the equitable utilization principle, by invoking Professor McCaffrey's following comment: ${ }^{.73}$ "[T]he primacy of the "no harm principle" means that the fundamental rights and obligations of States with regard to their uses of an international watercourse are more definite than they would be if governed in the first instance by the more flexible (and consequently less clear) rule of equitable utilization."174

On the other hand, Slovakia rebutted Hungary's argument, regarding the above statement as affirming "that it was felt not sufficient for the question of harm and damage to be addressed only indirectly through the provisions on equitable use", ${ }^{175}$ as is stated in the Commentary on Article 7 of the 1994 ILC Final Draft. ${ }^{176}$ According to Slovakia, "[e]ven if Hungary were able to show that the Project had caused it significant harm, this would not establish a breach of an obligation by Slovakia. It would instead be viewed in the overall context of the regime of the equitable utilization which Hungary helped to devise and construct, and in which Hungary is free to participate." 177

In the 1997 judgment the ICJ did not express itself on the relationship between the equitable utilization principle and the no harm principle. $^{178}$ It did not apply the latter principle ${ }^{179}$ though recognizing its existence under

172 See Hungary's Memorial Vol. 1 [hereinafter, HM] (2 May 1994), at 167-179, paras. 5.106-5.140; Hungary's Counter-Memorial Vol. 1 [hereinafter, HC-M] (5 December 1994), at 153-174, paras. 3.15-3.85; Hungary's Reply Vol. 1 [hereinafter, HR] (20 June 1995), at 90-99, paras. 2.50-2.74. Slovakia denied the existence of (the risk of) harm to Hungary. See Slovakia's Memorial Vol. 1 [hereinafter, SM] (2 May 1994) at 292, para. 7.44, at 305, para. 7.85; Slovakia's Counter-Memorial Vol. 1 [hereinafter, SC-M] (5 December 1994), at 344, para. 11.44; Slovakia's Reply Vol. 1 [hereinafter, SR] (20 June 1995), at 150-151, para. 6.85.

$173 \mathrm{HM}$, at 231, para. 7.79.

174 McCaffrey, op. cit. n. 74, at 510.

175 SC-M, at 338, paras. 11.24-11.26.

176 See 1994 ILC Report, op. cit. n. 3, at 236.

$177 \mathrm{SR}$, at 152, para. 6.87.

178 Alan E. Boyle, “The Gabčíkovo-Nagymaros case: new law in old bottles”, 8 Yearbook of International Environmental Law [hereinafter, YIEL] (1997) 13 at 16; Stephen Stec \& Gabriel E. Eckstein, "Of solemn oaths and obligations: the environmental impact of the ICJ's decision in the case concerning the Gabčíkovo-Nagymaros project", id., 41 at 46.

179 There seem to be at least three reasons, in addition to the purpose of avoiding the decision on the relationship between the equitable utilization principle and the no harm principle, why the ICJ did not apply the no harm principle in this case. First, it was difficult to decide on the existence of (the risk of) actual harm to Hungary caused by putting into operation of Variant C. See op. cit. n. 172. Secondly, It was difficult to decide on Slovakia's lack of "due diligence". See HC-M, at 
customary international law; ${ }^{180}$ instead it applied the equitable utilization principle $^{181}$ on a customary basis. ${ }^{182}$ Some authors are of the opinion that the judgment actually stands for the priority of the equitable utilization principle over the no harm principle. ${ }^{183}$ Among others, Professor Bourne ${ }^{184}$ argues as follows:

256, para. 6.133; SC-M, at 338, para. 11.26, at 341-343, paras. 11.37-11.42. Lastly, since in this case the Parties had already concluded a watercourse agreement, i.e., the 1977 Treaty concerning the construction and operation of the Gabčíkovo-Nagymaros System of Locks [hereinafter, the 1977 Treaty], there was some room for finding Hungary's consent in it to tolerate the possible harm. See SM, at 292, para. 7.44. See also Separate Opinion of Judge Koroma, ICJ Rep. 1997, at 149. Judge Oda, however, while respecting the agreement between the Parties on the diversion of water of the Danube, states as follows: "if the operation of the Cunovo dam diverting waters into the old Danube river bed has caused any tangible damage to Hungary, Slovakia should bear the responsibility for this mishandling of the division of waters.” Dissenting Opinion of Judge Oda, ICJ Rep. 1997, at 166 , para. 26 .

180 The ICJ cited the following passage of the ICJ Advisory Opinion on the Legality of the Threat or Use of Nuclear Weapons of 8 July 1996: "The existence of the general obligation of States to ensure that activities within their jurisdiction and control respect the environment of other States or of areas beyond national control is now part of the corpus of international law relating to the environment." (ICJ Rep. 1996, at 241-242, para. 29.) The Judgment, ICJ Rep. 1997, at 41, para. 53. No judge denied the existence of the no harm principle under customary international law; some judges even expressly referred to it. See Separate Opinion of Judge Koroma, id., at 149; Dissenting Opinion of Judge Herczegh, id., at 193. Both Parties, too, admitted it. See HM, at 219-223, paras. 7.45-7.56; HC-M, at 224-226, paras. 6.34-6.41; HR, at 133-134, paras. 3.56-3.57; SR, at 151, para. 6.86. Article 3, paragraph 1(b), of the Convention concluded between Hungary and Czechoslovakia on the Regulation of Water Management Issues of Boundary Waters (31 May 1976) provides as follows: "The Contracting Parties do hereby undertake that they shall maintain in good condition the beds of watercourses, reservoirs, and equipment located on boundary waters on their own territories and shall operate them in such a manner as to cause no damage to each other." See HM, at 215, paras. 7.25-7.26 and Annex 19 .

181 The ICJ held as follows. First, "the operation of Variant C led Czechoslovakia to appropriate ... between 80 and 90 per cent of the waters of the Danube", depriving Hungary of "its basic right to an equitable and reasonable sharing of the resources of an international watercourse". The Judgment, ICJ Rep. 1997, at 54, para. 78. Secondly, "Czechoslovakia, by unilaterally assuming control of a shared resource, and thereby depriving Hungary of its right to an equitable and reasonable share of the natural resources of the Danube ... failed to respect the proportionality which is required by international law". Id., at 56 , para. 85 .

182 While in the 1977 Treaty there was no provision expressly providing for the equitable utilization principle, the ICJ recognized the existence of that principle under customary international law by invoking the 1929 PCIJ River Oder case and the 1997 Watercourses Convention. See id., at 56, para. 85. See also, Lammers, "The Gabčíkovo-Nagymaros case seen in particular from the perspective of the law of international watercourses and the protection of the environment", 11 Leiden Journal of International Law (1998) 287 at 306.

183 Jochen Sohnle, "Irruption du droit de l'environnement dans la jurisprudence de la C.I.J.: l'affaire Gabčíkovo-Nagymaros", 102 RGDIP (1998) 85 at 113, footnote 115.

184 Charles B. Bourne, "The case concerning the Gabč́kovo-Nagymaros project: an important milestone in international water law", 8 YIEL (1997) 6. 
This denial [of absolute priority to any factor relating to the utilization of the waters of the Danube in this case ${ }^{185}$ was, in effect, a rejection by the ICJ of the more general principle...that a utilization of a watercourse is not lawful if it will cause significant harm to other watercourse States - a "no significant harm" rule. ${ }^{186}$ (...) Significantly, the Court made no reference to Articles 20 and 21 of the [1997 Watercourses] Convention, which deal, in particular, with protection and preservation of ecosystems and with pollution that may cause significant harm to the environment, thus, giving no credibility to the notion of the existence of a "no significant harm" rule that qualifies the principle of equitable utilization. ${ }^{187}$

However, the following three arguments may be put forward against his reasoning: first, the ICJ denied absolute priority to any factor through the interpretation of the objectives of the 1977 Treaty without considering the relationship between the equitable utilization principle and the no harm principle under customary international law; secondly, the absence of a reference to the "no significant harm" rule, which forms the basis of Article 20 and is expressly stipulated in Articles 7 and 21 of the 1997 Watercourses Convention, is a natural consequence of the ICJ's non-application of the no harm principle in this case; ${ }^{188}$ finally, there might have been some hesitation on the part of the ICJ to invoke the "no significant harm" rule as stipulated in the 1997 Watercourses Convention because the threshold of "significant" was thought to be lower than that of "serious" which was recognized under customary international law. ${ }^{189}$

For these reasons the case seems to offer little clarity about the relationship between the two principles under customary international law. In any case it may be said from this case that it is not necessary ${ }^{190}$ to make a pro-

\footnotetext{
185 See the Judgment, ICJ Rep. 1997, at 77, para. 135.

186 Bourne, op. cit. n. 184, at 7-8. He also adds as follows: "It [the judgment] establishes that the protection of the environment has no absolute priority over other considerations, particularly in the case of developments involving the utilization of international watercourses. These developments must be reasonable and equitable, a matter to be judged in the light of all relevant factors. Among these factors, the protection of the environment of other States is of high, but not overriding, importance." Id., at 11.

187 Id., at 10.

188 See op. cit. n. 179.

189 See 1987 ILC Report, op. cit. n. 15, at 29, para. 16; 1988 ILC Report, op. cit. n. 15, at 36, para. 5; 1994 ILC Report, op. cit. n. 3, at 211-212, paras. 13-15.

190 See Boyle, op. cit. n. 178, 8 YIEL (1997) 16; Paulo Canelas de Castro, "The judgment in the case concerning the Gabčíkovo-Nagymaros project: positive signs for the evolution of international water law", id., 21 at 23. However, it seems to become necessary to decide on the said relationship where the ICJ itself has to determine the exact range of the "equitable use" or the existence of a breach of the no (pollution) harm principle.
} 
nouncement on the said relationship in order to give an indication on a guideline for the negotiations to be held after a judgment. ${ }^{191}$

\section{AN OVERALL APPRAISAL}

On the basis of the foregoing examination, the following two observations may be made about pollution harm: first, under customary international law, the level of harm to be prevented, viz. serious harm, may not be raised further by the equitable utilization principle, in the phase of ex ante as well as in that of ex post prevention of harm; secondly, according to recent tendencies in State practice, a strict position is gradually being accepted by determining a lower level of harm to be prevented, viz. appreciable (=significant) harm, and by rejecting a raising of that level by the equitable utilization principle both in the phase of ex ante and in that of ex post prevention of harm, subject to contrary regulation by treaty. It may thus be concluded that the position of the 1997 Watercourses Convention is indeed in accord with the judicial precedents and State practice including its recent tendencies. Seen from this same perspective, the position of the ILA, which to a great extent recognized the "relaxation" of the obligation not to cause the higher level of harm as denoted by the term "substantial injury", should be criticized for lacking a basis in the positive law. In the same way, Caflisch's suggestion to adopt the "mitigated no-substantial-harm principle" for pollution harm might well maintain its validity so far as no serious harm occurs.

In conclusion, the equitable utilization principle, whose essence lies in the balancing of interests, is not allowed to raise the level of pollution harm to be prevented to a level as high as serious harm, and its operation is apt to remain extremely limited even in that case. ${ }^{192}$ This conclusion would of course be criticized by those who support Caflisch's view because of the ambiguity of such concepts as serious harm and appreciable (=significant) harm. While it is true that these concepts are ambiguous, yet it seems that they are simpler and more objective than both the equitable utilization principle, which requires all relevant factors to be taken into account, and the "mitigated no-substantial-harm principle", which admits a high disproportion

191 See the Judgment, ICJ Rep. 1997, at 75-76, para. 131. Hungary asked the ICJ to indicate such a guideline during the oral proceedings. See the statement of Dr. Szenasi (Hungary), ICJ Verbatim Record $97 / 13$, at 80 , para. 7 .

192 According to Dr. Wouters, in the Garrison Diversion Project on the diversion from the Missouri river planned by the United States, the IJC (see op. cit. n. 162) adopted a broad interpretation of the concept of pollution in its report, taking account of the principle of equitable utilization of international watercourses. See Wouters, op. cit. n. 163, at 70-73, 84. According to the reasoning of that report, there is of course the possibility that the level of harm to be prevented is pulled down by the equitable utilization principle. This author does not exclude such a possibility, either. See op. cit. n. 70 . 
between the costs needed to reduce pollution and the benefits gained by that reduction. For a proper understanding of the concept of "serious" harm the Trail Smelter case provides prima facie criteria. Besides, the following criteria are most useful in determining the meaning of "irreparable harm", which should in turn be regarded as the core of serious harm: (1) "a substantial deterioration in living conditions for a large number of people or a significant loss from the standpoint of nature conservancy" as stated in the 1971 FinnishSwedish Agreement concerning Frontier Rivers; (2) "threat to human health and safety" stated in Rosenstock's first report of 1993 and the commentary on Article 7 of the 1994 Final Draft; (3) Poland's observation, as follows: “... Article 7 [of the Provisional Draft concerning the obligation not to cause appreciable harm] is a certain security network for Article 5 [of the Provisional Draft concerning the equitable utilization principle] - that is, situations in which negotiations fail." 193 These observations mean that we should recognize the notions of appreciable (=significant) or serious harm, despite their ambiguity, and prescribe an obligation not to cause "factual harm" of these levels. Otherwise, the risk of continuous pollution would greatly increase in case of failure of negotiations, unless the question of whether or not the activity in question falls into the range of "an equitable use" is answered and decided by third party judgment.

Can it be held that this conclusion also applies to cases concerning other components of the ecosystem belonging to the "shared natural resources"? It is suggested that this is a basically separate question that cannot be answered easily. ${ }^{194}$ Among other factors that would have to be examined specifically is whether the "equitable utilization principle", if applied to "shared natural resources" other than international watercourses, has the same contents as if applied to international watercourses. However, if the use of a certain component of the ecosystem within a State necessarily has an impact on the use of the same component within another State, ${ }^{195}$ it seems reasonable to assume the existence of a general principle of equitable utilization of "shared natural resources". 196 The essence of the principle would lie in the balancing of interests, assuming that a "community of interest" exists, which "becomes the basis of a common legal right" as stated by the PCIJ in the River Oder case.

If an "equitable utilization principle" be assumed to have been established for a certain component of the ecosystem in a certain area, the foregoing

\footnotetext{
193 UN Doc., A/C.4/447/Add.1, at 10.

194 For example, there were some arguments whether the 1994 Final Draft should be applied to "confined transboundary groundwater" unrelated to surface water. The resolution adopted at the final stage merely states that States should be guided by the principles contained in the Final Draft in regulating transboundary groundwater. See 1994 ILC Report, op. cit. n. 3, at 326.

195 See Handl, op. cit. n. 10, at 41, footnote 2.

196 But see, for example, Patricia W. Birnie \& Alan E. Boyle, International law and the environment (Oxford: Clarendon Pr., 1992), at 316-317.
} 
analysis could be useful. One might think of cases of pollution of a (semi-) enclosed sea or adjacent coastal waters and also, in view of the existing analogy between water pollution and air pollution as suggested by the Trail Smelter case, of cases of regional transfrontier air pollution among neighbouring States. ${ }^{197}$ In considering such analogies, however, we should, of course, duly keep in mind the existing differences between the characteristics of the components.

Finally, the determination of the desirable degree of preventive measures may become difficult if the level of harm to be prevented is fixed by the principle of equitable utilization of international watercourses or other "shared natural resources". Besides, various factors are to be taken into account in deciding whether or not that level is exceeded. Consequently, it would not be easy to charge the State of origin with responsibility for its failure to take the necessary preventive measures. In view of all this the need for some mechanism to implement the equitable utilization principle becomes particularly necessary. ${ }^{198}$

\section{CONCLUSION: THE NECESSITY OF HARMONIZING INTRA- GENERATIONAL EQUITY WITH INTER-GENERATIONAL EQUITY}

This article has tried to demonstrate that the "relaxation" of the no pollution harm principle by the equitable utilization principle is allowed only to an extremely limited extent, in so far as serious harm does not occur. Accordingly, environmental protection is promoted by prevention of "factual harm". The position will likely be criticized as favouring the interests of developed countries. However, it should not be forgotten that considerations of sustainable development as well as the protection of the interests of future generations are also operative in the area of transfrontier pollution, as was pointed out by McCaffrey in the ILC. These concepts have now been intro-

197 See Magraw et al., Fourth Report on LDAP, op. cit. n. 12, at 26-36, paras. 91-116. Professor Handl draws, from an analysis of customary international law, the following conclusion concerning transfrontier air pollution: first, there has been established the obligation of States to avoid any use that entails significant transboundary harm, and the occurrence of significant harm gives rise to a presumption of illegality, which could be rebutted only upon demonstration of a need for an " $a d$ hoc adjustment"; secondly, transfrontier harm which is less than the significant level but is the appreciable level or over is subject to the "balancing of interests" test. Handl, op. cit. n. 12, at 419,465 . Since he, on the one hand, regards significant harm as including both serious harm and appreciable (=significant) harm in the ILC's understanding, and, on the other hand, regards appreciable harm as detectable (=measurable) harm in that understanding, it is impossible to make a simple comparison between his conclusion and that of this paper. However, the conclusions of the two are the same at least at the point that the "balancing of interests" test deems inapplicable when "factual harm" exceeds a certain level.

198 See McCaffrey, "Current developments: the forty-third session of the International Law Commission”, 85 AJIL (1991) 703 at 706, footnote 14. 
duced into positive international law, witness the following pieces of evidence: Principles 1 and 3 of the Rio Declaration on Environment and Development of 1992; ${ }^{199}$ Article 3, paragraphs 1 and 4, of the United Nations Framework Convention on Climate Change; ${ }^{200}$ Article 5, paragraph 1, of the 1997 Watercourses Convention; ${ }^{201}$ and the 1997 ICJ decision in the Gabč́kovoNagymaros Project case. ${ }^{202}$ It is understandable that the consideration of inter-generational equity ${ }^{203}$ on which the above concepts are based should be respected in the context of the utilization of international watercourses, since a whole chapter, viz. Chapter 18 (entitled "Protection of the quality and supply of freshwater resources") is devoted to the topic in "Agenda 21" as adopted by the United Nations Conference on Environment and Development of 1992. ${ }^{204}$ In fact, Article 2, paragraph 5(c), of the 1992 Transboundary Watercourses Convention provides that "[w]ater resources shall be managed so that the needs of the present generation are met without compromising the ability of future generations to meet their own needs". ${ }^{205}$ Therefore, the equitable utilization principle should be interpreted so as to harmonize with inter-generational equity. Thus we come to the conclusion that the equitable utilization principle should not be regarded as a legal basis for allowing an increase of pollution from developing countries, but as one for helping these countries to receive budgetary or technical assistance for pollution prevention. ${ }^{206}$ It should never be admitted that the rejection of the "relaxation" of the no pollution harm principle by the equitable utilization principle would result in producing advantages for the developed countries only.

\footnotetext{
19931 ILM (1992) 874.

200 Id., at 849.

20136 ILM (1997) 705.

202 See the Judgment, ICJ Rep. 1997, at 78, para. 140. See also Separate Opinion of Vice-President Weeramantry, id., at 88-111.

${ }^{203}$ See generally Edith Brown Weiss, In fairness to future generations (Tokyo: The United Nations University, 1989). See also HANDL, "Environmental security and global change: the challenge to international law", 1 YIEL (1990) 3 at 24-27.

204 See Stanley P. Johnson (ed.), The Earth Summit: The United Nations Conference on Environment and Development (UNCED) (London: Graham \& Trotman, 1993), at 123.

20531 ILM (1992) 1316.

206 Weiss, op. cit. n. 203, at 27-28.
} 